\title{
Trace Elements in Marine Environments: Occurrence, Threats and Monitoring with Special Focus on the Coastal Mediterranean
} Jonathan Richir ${ }^{1,2^{\star}}$ and Sylvie Gobert ${ }^{2}$

${ }^{1}$ Numerical Ecology of Aquatic Systems, University of Mons, Pentagone 3D08, 6, Avenue du Champ de Mars, 7000 Mons, Belgium ${ }^{2}$ Laboratory of Oceanology, MARE Centre, University of Liege, B6C, 4000 Liege, Sart Tilman, Belgium

\begin{abstract}
Trace elements, as building blocks of matter, are naturally present in the environment. However, their extraction, production, use and release by men can lead to the increase of their environmental levels to concentrations that may be toxic for both men and the biota. The overall aim of this review is therefore to recall that trace elements remain contaminants of concern that still require scientific attention. Because marine coastal systems (and transitional environments in general) are particularly vulnerable to contamination processes, they deserve to be accurately monitored with quality indicator species. As an example, the 2 most widely quality indicator species used to assess the health status of the coastal Mediterranean are the seagrass Posidonia oceanica and the mussel Mytilus galloprovincilias. In this review, after a short introduction on human pressures on the World Ocean and the coastal Mediterranean in particular (1), we will redefine the term trace element from an environmental perspective and discuss their accumulation and toxicity for men and the biota (2). We will consider the benefits of using biological indicators instead of water and sediment measurements to assess the health status of the marine environment (3), and more particularly as regards the accurate and complementary indicators that are seagrasses (4) and mussels (5)
\end{abstract}

Keywords: Trace element; Toxicity; Aquatic environment; Monitoring; Seagrass; Mussel; Mediterranean

\section{Introduction}

Such as terrestrial ecosystems, marine ecosystems are submitted to increasing anthropogenic disturbances [1]. On the basis of expert judgment, Halpern et al. [2,3] mapped the impact of 17 anthropogenic drivers of ecological change (e.g., pollution, fishing, ocean acidification, species invasion etc.) on marine ecosystems. Their analysis indicated that no area remained unaffected by human activities, that a large fraction of the oceans was strongly affected by those drivers (41\%), but that some large, less-impacted oceanic areas still remained (3.7\%, particularly near the poles). The ecologic, economic and social importance of marine ecosystems being irrefutable [1,4], a wellplanned approach of managing the marine space is essential to achieve sustainability [1]. Otherwise, entire ecosystems will stop functioning under their actual form, as is the case for the highly productive hotspots of biodiversity that are coral reefs [5], which is likely to lead to the complete loss of goods and services derived from these ecosystems [6].

The Mediterranean is one of the richest regions of Europe in terms of diversity of marine species with a high rate of endemism [7]. In the Mediterranean, coastal ecosystems are dominated by macrophytes (magnoliophytes and algae) [8], a globally net autotrophic system displaying many ecological benefits (e.g., primary production, habitats, source of food and oxygen, carbon well, stabilization of sediments etc.) [9]. Despite their environmental, economic and social importance, a growing number of reports document the occurring regression and/ or ecofunctional changes of these coastal ecosystems (e.g., Ref. [1012]). Pressures suffered by the Mediterranean make it a vulnerable ecological unit, in particular because this sea is of too small dimensions to ecologically self-counterbalance. Thus, the point of saturation of the contaminants discharged in the Mediterranean will be more quickly achieved than in the oceans [13]. And as regards the specific chemical contamination by trace elements, the high levels currently measured in the Mediterranean indicate non-stationary geochemical cycles which result from an increase of external inputs [14]. In addition, the almost total absence of tide does not allow the dilution of contaminants and prevents the natural phenomena of depuration as encountered in larger water bodies (i.e., in oceans). The Mediterranean also shows a deficiency in the movement of its deep water masses and of its surface currents which "turn in circles" in this almost closed basin. The consequence of these specific features is that the answer of the Mediterranean to environmental disturbances is more rapid than in the larger oceans $[15,16]$ which makes of this sea a privileged laboratory to study environmental changes resulting from anthropogenic pressures [17].

\section{Trace Elements}

\section{Definition}

According to the International Union of Pure and Applied Chemistry [18], trace elements are any element having an average concentration of less than about 100 parts per million atoms (ppma) or less than $100 \mu \mathrm{g} \mathrm{g}^{-1}$. Such a precise definition does not exist in earth sciences because the concentration of an element in a given phase can be so low that it is considered a trace element, whereas the same element can constitute a main part of another phase (e.g., Fe and Al) [19]. Previously, scientists used the generic term "heavy metals" when referring to trace elements. Today this appellation is discussed. Effectively, some metals are not particularly "heavy" (e.g., Al, Ni). In addition, some elements are not metals (e.g., As, Se). For these reasons, the majority of researchers prefer today the name "metallic trace elements" (if it is indeed metals) to the appellation "heavy metals", or the formula "trace elements" when they are not metals (e.g., As, Se, B) [20]. In the present review, we will consider trace elements (acronym TEs used throughtout the paper) as any element, metallic or not, other

*Corresponding author: Jonathan Richir, Numerical Ecology of Aquatic Systems, University of Mons, Pentagone 3D08, 6, Avenue du Champ de Mars, 7000 Mons, Belgium, Tel: 3243662111; E-mail: jonathan.richir@alumni.ulg.ac.be

Received October 12, 2015; Accepted January 21, 2016; Published January 25 2016

Citation: Richir J, Gobert S (2016) Trace Elements in Marine Environments: Occurrence, Threats and Monitoring with Special Focus on the Coastal Mediterranean. J Environ Anal Toxicol 6: 349. doi:10.4172/2161-0525.1000349

Copyright: ( 2016 Richir J, et al. This is an open-access article distributed under the terms of the Creative Commons Attribution License, which permits unrestricted use, distribution, and reproduction in any medium, provided the original author and source are credited. 
than the few major constitutive ones (i.e., C, $\mathrm{H}, \mathrm{N}, \mathrm{S}, \mathrm{O}, \mathrm{P}, \mathrm{Si}, \mathrm{Cl}, \mathrm{K}, \mathrm{Na}$, $\mathrm{Ca}$ and $\mathrm{Mg}$ ) forming the bulk of living and mineral (except $\mathrm{Fe}$ and $\mathrm{Al}$ ) matter, whose concentrations are mostly below but sometimes above 100 ppma according to the matrice analysed (Figure 1) [21,22].

TEs can either be essential or non-essential (Figure 1). The essential elements recognized by the World Health Organization (WHO) are $\mathrm{I}, \mathrm{Zn}, \mathrm{Se}, \mathrm{Fe}, \mathrm{Cu}, \mathrm{Cr}$ and $\mathrm{Mo}$, the latter playing an important role in biological systems $[23,24]$. Others TEs may/could also be essential, such as Mn, Co, As, Ni or V. For these elements among others, the essentiality is a characteristic which evolves according to our knowledge and to the sensitivity of the authors who have a propensity more or less strong to classify an element among the essential or not [25]. Nonessential TEs such as $\mathrm{Hg}, \mathrm{Pb}$ or $\mathrm{Cd}$ play no physiological role, and are often toxic even in very small quantity [26]. For these non-essential TEs, only a threshold of toxicity exists, while essential TEs can be either deficient in too small quantities, either toxic when they are absorbed in high concentrations [25].

\section{Production and uses}

The world refinery and mine production of most TEs except a few (e.g., As, $\mathrm{Cd}, \mathrm{Pb}, \mathrm{Sn}$ ) have substantially increased since the $80 \mathrm{~s}$ (e.g., Fe, Al, Mo) and particularly since the beginning of years 2000 (Table 1). World demand for minerals is affected by 3 general factors: (i) uses for mineral commodities, (ii) the level of population that will consume these mineral commodities and (iii) the standard of living that will determine just how much each person consumes [27]. Today, with the integration of India, the People's Republic of China and other populous developing and emerging countries (e.g., Brazil and Russia) into the world economy, more than $50 \%$ of the world's population (instead of the previous 20\%) account for the largest part of raw materials consumption $[28,29]$. The increasing demand for mineral raw materials further concerns numerous "emerging elements". These elements can be "truly emerging" because they have just gained entry to the environment (new commercial uses and industrial releases) or have nowadays become contaminants "of emerging concern" while they were not in the past (new advances in analytical chemistry, new knowledge on their toxicity, new environmental compartments explored) [30,31].

The use of these emerging chemicals are multiple and diverse. For example, $\mathrm{V}$ is regarded as one of the hardest of all metals. This ubiquitous TE is employed in a wide range of alloys for numerous commercial applications extending from train rails, tool steels, catalysts, to aerospace [32]. Sb greatly increases the hardness and the mechanical strength of $\mathrm{Pb}$, and is found in batteries, antifriction alloys, type-metal, small arms and tracer bullets, and cable sheathing. It further has many uses as a flame retardant (in textiles, papers, plastics and adhesives), as a paint pigment, ceramic opacifier, catalyst, mordant and glass decolouriser, and as an oxidation catalyst [33,34]. Bi is largely consumed in low-melting alloys and metallurgical additives, including electronic and thermoelectric applications. The remainder is used for catalysts, pearlescent pigments in cosmetics, pharmaceuticals, and industrial chemicals [35].

\section{Human toxicity}

The major exposure media to TEs for humans are food, water and air [36]. Safe drinking water supply is a high priority issue for safeguarding the health and well-being of humans [37,38] and is an important development issue [37]. Although standards legislate the acceptable levels of contaminants in drinking water (Table 2),

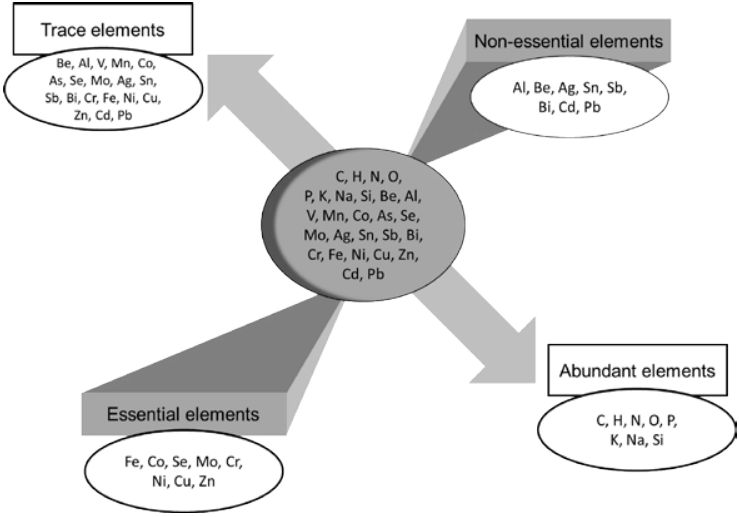

Figure 1: Some essential and non-essential elements, abundant or in traces (modified after Ref. [25])

$[26,37,39-41]$ the supply of quality water remains a major challenge for humanity in the $21^{\text {st }}$ century [42]. The spectrum of adverse effects caused by the consumption of contaminated water is huge and ranges from relatively harmless to life threatening (Table 2) [38]. For example, populations exposed to inorganic As via drinking water showed excess risk of mortality from lung, bladder and kidney cancer and an increased risk of skin cancer and other skin lesions such as hyperkeratosis and pigmentation changes [43]. Japanese who consumed Cd polluted rice and river water accumulated in their bodies a large amount of $\mathrm{Cd}$ that lead to a serious osteoporosis-like bone disease, the "itai-itai byo" or "ouch-ouch disease" [44]. And in some of the great Cairo cities, Egypt, renal failure was related to $\mathrm{Pb}$ and $\mathrm{Cd}$ contamination of ground drinking water [45].

Essential micronutrient may also show toxic effects when ingested at too high levels, as reviewed by Goldhaber [46] and widely detailed in Nordberg et al. [26]. The ingestion of very high doses of $\mathrm{Cr}$ causes liver and kidney problems. Abdominal pain, cramps, nausea, diarrhea, and vomiting have been caused by the consumption of beverages containing high levels of $\mathrm{Cu}$ and liver damage has been seen in individuals with diseases of $\mathrm{Cu}$ metabolism. The consumption of Mn-containing well water has caused lethargy, tremor, and mental disturbances in Japan and neurologic symptoms were reported in individuals exposed to $\mathrm{Mn}$ contaminated drinking water in Greece.

\section{Sources of TEs in the sea}

Continental runoff and atmospheric deposition are the primary natural inputs of TEs in the marine environment [47]: crustal material is either weathered on (dissolved) and eroded from (particulate) the Earth's surface or injected into the atmosphere by volcanic activity. Forest fires and biogenic sources are of a lesser importance $[48,49]$. In addition to these natural sources, there exists a multitude of anthropogenic emission sources, the major ones resulting from mining and smelting activities [47]. Other important land-based anthropogenic sources of TEs result from the growth of industrial, agricultural and urban activities since the early-60s (e.g., Ref. [50-52]). According to the United Nations [53], more than $80 \%$ of the pollution of the seas comes from inland via the rivers or through runoff and discharges from the coastal areas. As at least $60 \%$ of the world's population live within 100 $\mathrm{km}$ of the coast, the contamination of coastal waters may pose serious risks to human health as well as marine ecosystems [52]. 
Citation: Richir J, Gobert S (2016) Trace Elements in Marine Environments: Occurrence, Threats and Monitoring with Special Focus on the Coastal Mediterranean. J Environ Anal Toxicol 6: 349. doi:10.4172/2161-0525.1000349

Page 3 of 19

\begin{tabular}{|c|c|c|c|c|c|c|}
\hline \multirow[t]{2}{*}{ Trace element } & \multirow[t]{2}{*}{ Symbol } & \multicolumn{5}{|c|}{ Year } \\
\hline & & 1990 & 2000 & $\lambda_{(1990)}$ & 2010 & $\nearrow_{(1990)}$ \\
\hline Aluminum & $\mathrm{Al}$ & 17,817 & 24,400 & $37 \%$ & 40,800 & $129 \%$ \\
\hline Antimony & $\mathrm{Sb}$ & 83.2 & 122 & $47 \%$ & 167 & $101 \%$ \\
\hline Arsenic & As & 47.6 & 36.9 & $-23 \%$ & 52.8 & $11 \%$ \\
\hline Beryllium & $\mathrm{Be}$ & 0.286 & 0.226 & $-21 \%$ & 0.203 & $-29 \%$ \\
\hline Bismuth & $\mathrm{Bi}$ & 3.33 & 3.75 & $13 \%$ & 8.47 & $154 \%$ \\
\hline Cadmium & $\mathrm{Cd}$ & 20.2 & 20.2 & $0 \%$ & 21.4 & $6 \%$ \\
\hline Chromium & $\mathrm{Cr}$ & 12,846 & 4,320 & $-66 \%$ & 7,290 & $-43 \%$ \\
\hline Cobalt & Co & 37.1 & 33.3 & $-10 \%$ & 89.5 & $141 \%$ \\
\hline Copper & $\mathrm{Cu}$ & 8.8 & 13.2 & $50 \%$ & 16.0 & $82 \%$ \\
\hline Iron & $\mathrm{Fe}$ & 543,000 & $1,061,148$ & $95 \%$ & $2,590,000$ & $377 \%$ \\
\hline Lead & $\mathrm{Pb}$ & 3,367 & 3,100 & $-8 \%$ & 4,140 & $23 \%$ \\
\hline Manganese & $\mathrm{Mn}$ & 27.2 & 20.2 & $-26 \%$ & 42.7 & $57 \%$ \\
\hline Molybdenum & Mo & 112 & 129 & $16 \%$ & 242 & $117 \%$ \\
\hline Nickel & $\mathrm{Ni}$ & 1,029 & 1,250 & $21 \%$ & 1,590 & $54 \%$ \\
\hline Selenium & $\mathrm{Se}$ & 1,789 & 1,460 & $-18 \%$ & 2,120 & $19 \%$ \\
\hline Silver & $\mathrm{Ag}$ & 17.7 & 18.4 & $4 \%$ & 23.1 & $31 \%$ \\
\hline Tin & Sn & 219 & 238 & $9 \%$ & 265 & $21 \%$ \\
\hline Vanadium & V & 31.0 & 43.0 & $39 \%$ & 57.6 & $86 \%$ \\
\hline Zinc & $\mathrm{Zn}$ & 7,325 & 8,730 & $19 \%$ & 12,000 & $64 \%$ \\
\hline
\end{tabular}

Table 1: World production of 19 trace elements for the years 1990, 2000 and 2010, and percentage of increase by decade (data compiled from the Mineral Yearbooks published on the US Geological Survey website, www.usgs.gov).

\begin{tabular}{|c|c|c|c|}
\hline $\begin{array}{l}\text { Trace } \\
\text { element }\end{array}$ & $\begin{array}{c}\text { Guideline values } \\
(\mathrm{ppm}) \text { from the WHO, } \\
\text { the EPA and HC }\end{array}$ & Common sources of trace elements in drinking water & Potential human health effects \\
\hline $\mathrm{Al}$ & $\begin{array}{l}\text { WHO: } 0.9(<0.1 \text { in } \\
\text { conventional treatment } \\
\text { plants; }<0.2 \text { in other } \\
\text { treatment types) }\end{array}$ & $\begin{array}{c}\text { Erosion of natural deposits; Al salts used as flocculents during } \\
\text { the treatment of drinking water. }\end{array}$ & $\begin{array}{c}\text { Little indication that orally ingested } \mathrm{Al} \text { is acutely toxic to humans; } \\
\text { no adverse health effect at levels found in drinking water; } \mathrm{Al} \\
\text { exposure is a risk factor for the development or acceleration of } \\
\text { onset of Alzheimer disease. }\end{array}$ \\
\hline $\mathrm{Sb}$ & $\begin{array}{l}\text { WHO: } 0.020 ; \text { EPA, } \\
\text { HC: } 0.006\end{array}$ & $\begin{array}{l}\text { Erosion of natural deposits; discharge from petroleum } \\
\text { refineries; fire retardants; ceramics; electronics; solders; } \\
\text { contaminants from pipes and fittings. }\end{array}$ & $\begin{array}{l}\text { Increase in blood cholesterol; decrease in blood sugar; } \\
\text { microscopic changes in organs and tissues (thymus, kidney, } \\
\text { liver, spleen, thyroid). }\end{array}$ \\
\hline As & WHO, EPA: 0.01 & $\begin{array}{l}\text { Erosion of natural deposits (erosion and weathering of soils, } \\
\text { minerals, ores); runoff from orchards; runoff from glass and } \\
\text { electronic production wastes. }\end{array}$ & $\begin{array}{l}\text { Skin damage or problems with the circulatory system; increased } \\
\text { risk of getting cancer (lung, bladder, liver, skin - classified as } \\
\text { human carcinogen); neurological effects (numbness and tingling } \\
\text { of extremities). }\end{array}$ \\
\hline $\mathrm{Be}$ & $\begin{array}{l}\text { WHO: } 0.010 \text {; EPA: } \\
0.004\end{array}$ & $\begin{array}{l}\text { Discharge from metal refineries and coalburning factories; } \\
\text { discharge from electrical, aerospace and defense industries. }\end{array}$ & $\begin{array}{l}\text { Intestinal lesions; rarely found in drinking-water at concentrations } \\
\text { of health concern. }\end{array}$ \\
\hline $\mathrm{Bi}$ & No guideline value & Concentrations of $\mathrm{Bi}$ in drinking water have not been reported. & $\begin{array}{l}\text { Doses used in medicines are very much larger than the } \\
\text { estimated dietary exposure; dietary exposures to } \mathrm{Bi} \text { are unlikely } \\
\text { to be of toxicological concern. }\end{array}$ \\
\hline $\mathrm{Cd}$ & $\begin{array}{l}\text { WHO: } 0.003 \text {; EPA, } \\
\text { HC: } 0.005\end{array}$ & $\begin{array}{c}\text { Erosion of natural deposits; corrosion of galvanized pipes; } \\
\text { discharge from metal refineries; runoff from waste batteries } \\
\text { and paints; leaching from solders or black polyethylene pipes; } \\
\text { industrial and municipal wastes. }\end{array}$ & $\begin{array}{c}\text { Kidney damage; softening of bone; classified as human } \\
\text { carcinogen. }\end{array}$ \\
\hline $\mathrm{Cr}$ & $\begin{array}{l}\text { WHO, HC: } 0.05 ; \text { EPA: } \\
\quad 0.010\end{array}$ & $\begin{array}{l}\text { Erosion of natural deposits; releases or spills from industrial } \\
\text { uses (steel and pulp mills). }\end{array}$ & $\begin{array}{l}\text { Enlarged liver; irritation of the skin, respiratory and } \\
\text { gastrointestinal tracts; kidney problems. }\end{array}$ \\
\hline Co & No guideline value & $\begin{array}{l}\text { Drinking water has a low-Co content, usually between } 0.0001 \\
\text { and } 0.005 \mathrm{ppm} .\end{array}$ & $\begin{array}{l}\text { Cardiovascular effects (cardiogenic shock, sinus tachycardia, } \\
\text { left ventricular failure, and enlarged hearts) observed in people } \\
\text { who consumed large amounts of beer over several years time } \\
\text { containing Co sulfate as a foam stabilizer; effects (nausea, } \\
\text { vomiting, and diarrhea), effects on blood, liver injury, and allergic } \\
\text { dermatitis have also been reported in humans from oral exposure } \\
\text { to Co. }\end{array}$ \\
\hline $\mathrm{Cu}$ & $\begin{array}{l}\text { WHO: } 2 \text {; EPA: TT } \\
\text { Action Level=1.3; } \\
\qquad \mathrm{HC}<1.0\end{array}$ & $\begin{array}{l}\text { Erosion of natural deposits (erosion and weathering of rocks } \\
\text { and minerals); corrosion of household plumbing systems; } \\
\text { contaminants from pipes and fittings; acidic mine water } \\
\text { drainage; landfill leachates; sewage effluents; iron-related } \\
\text { industries. }\end{array}$ & $\begin{array}{l}\text { Short term exposure: gastrointestinal distress; long-term } \\
\text { exposure: liver or kidney damages. Cu is an essential element in } \\
\text { human metabolism; adverse health effects occur at levels much } \\
\text { higher than the aesthetic objectives. }\end{array}$ \\
\hline $\mathrm{Fe}$ & $\begin{array}{l}\text { HC: aesthetic } \\
\text { objectives } \leq 0.3\end{array}$ & $\begin{array}{l}\text { Erosion of natural deposits (erosion and weathering of rocks } \\
\text { and minerals); use of Fe coagulants; corrosion of steel and } \\
\text { cast iron pipes. }\end{array}$ & $\begin{array}{l}\text { Not of health concern at levels causing acceptability problems in } \\
\text { drinking-water. }\end{array}$ \\
\hline
\end{tabular}




\begin{tabular}{|c|c|c|c|}
\hline $\mathrm{Pb}$ & $\begin{array}{l}\text { WHO, HC: } 0.010 \\
\text { EPA: TT Action } \\
\text { Level }=0.015\end{array}$ & $\begin{array}{l}\text { Erosion of natural deposits; corrosion of plumbing systems } \\
\text { (pipes, solders, brass fittings and lead service lines); } \\
\text { contaminants from pipes and fittings. }\end{array}$ & $\begin{array}{l}\text { Infants and children (under } 6 \text { years): delays in physical or mental } \\
\text { development; neurobehavioural effects; children could show } \\
\text { slight deficits in attention span and learning abilities. Adults: } \\
\text { kidney problems; high blood pressure. Others: anaemia; central } \\
\text { nervous system effects; in pregnant women, can affect the } \\
\text { unborn child; classified as probably carcinogenic to humans. }\end{array}$ \\
\hline $\mathrm{Mn}$ & $\begin{array}{l}\text { WHO: } 0.4 \\
\text { HC: aesthetic } \\
\text { objectives } \leq 0.05\end{array}$ & $\begin{array}{c}\text { Erosion and weathering of rocks and minerals; naturally } \\
\text { occurring in many surface water and groundwater sources, } \\
\text { particularly in anaerobic or low oxidation conditions (the most } \\
\text { important source for drinking-water). }\end{array}$ & $\begin{array}{c}\begin{array}{c}\text { Not of health concern at levels causing acceptability problems in } \\
\text { drinking-water. }\end{array}\end{array}$ \\
\hline Mo & WHO: 0.02 & Contaminations may occur in areas where Mo ore is mined. & $\begin{array}{l}\text { Occurs in drinking-water at concentrations well below those of } \\
\text { health concern. }\end{array}$ \\
\hline $\mathrm{Ni}$ & WHO: 0.07 & $\begin{array}{c}\text { Ni levels range from } 0.002 \text { to } 0.010 \mathrm{ppm} \text { in fresh and tapwater; } \\
\text { water is generally a minor contributor to the total daily oral } \\
\text { intake; the Ni contribution from water may be significant where } \\
\text { there is heavy pollution, in areas where Ni occurs naturally in } \\
\text { groundwater, where there is use of certain types of kettles of } \\
\text { non-resistant material in wells or when water has come into } \\
\text { contact with Ni-plated taps; released from fittings; released } \\
\text { from industrial Ni deposits. }\end{array}$ & Lack of evidence of a carcinogenic risk from oral exposure to $\mathrm{Ni}$. \\
\hline Se & $\begin{array}{l}\text { WHO: } 0.04 \text {; EPA: } \\
\text { 0.05; HC: } 0.01\end{array}$ & $\begin{array}{l}\text { Naturally occurring (erosion and weathering of rocks and } \\
\text { soils); discharge from petroleum and metal refineries; } \\
\text { discharge from mines. }\end{array}$ & $\begin{array}{l}\text { Toxic effetcs: hair or fingernail losses at extremely high levels of } \\
\text { exposure; numbness in fingers or toes; circulatory problems. }\end{array}$ \\
\hline $\mathrm{Ag}$ & $\begin{array}{l}\text { WHO: available data } \\
\text { inadequate to permit } \\
\text { derivation of health- } \\
\text { based guideline value; } \\
\text { EPA: } 0.1\end{array}$ & $\begin{array}{l}\text { Naturally occurring (erosion and weathering of rocks and } \\
\text { soils); drinking water, not treated with Ag for disinfection } \\
\text { purposes, usually contains extremely low concentrations of } \\
\text { Ag. }\end{array}$ & $\begin{array}{l}\text { Water-soluble Ag compounds such as nitrate have a local } \\
\text { corrosive effect and may cause fatal poisoning if swallowed } \\
\text { accidentally. }\end{array}$ \\
\hline $\mathrm{Sn}$ & No guideline value & $\begin{array}{l}\text { Drinking-water is not a significant source of } \mathrm{Sn} \text {; increasing use } \\
\text { of } \mathrm{Sn} \text { in solder, which may be used in domestic plumbing, and } \\
\text { proposed for use as a corrosion inhibitor. }\end{array}$ & $\begin{array}{c}\text { Occurs in drinking-water at concentrations well below those of } \\
\text { health concern; main adverse effect of excessive levels of } \mathrm{Sn} \text { in } \\
\text { canned beverages or other canned foods has been acute gastric } \\
\text { irritation; no evidence of adverse effects in humans associated } \\
\text { with chronic exposure to Sn. }\end{array}$ \\
\hline V & No guideline value & $\begin{array}{c}\text { Typical values of } \mathrm{V} \text { concentrations in drinking water are below } \\
\text { the detection limit. }\end{array}$ & $\begin{array}{l}\text { The main source of } V \text { intake is food; } V \text { little absorbed in the } \\
\text { gastro-intestinal tract and mainly eliminated unabsorbed with the } \\
\text { faeces. }\end{array}$ \\
\hline $\mathrm{Zn}$ & $\begin{array}{l}\text { HC: aesthetic } \\
\text { objectives } \leq 0.05\end{array}$ & $\begin{array}{l}\text { Naturally occurring; industrial and domestic emissions; } \\
\text { leaching may occur from galvanized pipes, hot water tanks } \\
\text { and brass fittings; } \mathrm{Zn} \text { concentrations in water from active or } \\
\text { inactive mines can be substantial. }\end{array}$ & $\begin{array}{l}\text { Not of health concern at levels found in drinking-water; effects on } \\
\text { human health by contamination on water supplies must be rare. }\end{array}$ \\
\hline
\end{tabular}

Table 2: Trace element guildeline values (ppm) for drinking water, common sources of trace elements in drinking water and potential effects on human health. Data compiled from the World Health Organization (WHO) [37], the United States Environmental Protection Agency (EPA) [39], Health Canada (HC) [40], Nordberg et al. [26] and the Committee on Toxicity of Chemicals in Food, Consumer Products and the Environment (COT) [41]. Treatment Technique (TT) Action Level: US drinking water requiring a treatment process in order to reduce the level of a contaminant.

\section{Removal processes from seawater}

Unlike organic pollutants that can be degraded to less harmful components by biological or chemical processes, TEs are considered as non-degradable pollutants [19,54]. This persistent character of TEs can alter, sometimes quite strongly, their natural biogeochemical balance in contaminated environments [55]. Processes removing TEs from seawater firstly include active biological uptake processes [56]. TEs are mainly transported into biological cells in ionic form through ionic channels. In addition, specific transport mechanisms cross the membrane barrier like binding with membrane carrier proteins or transport through hydrophilic membrane channels. Lipid-soluble (non-polar) metal forms including alkyl-TE compounds and neutral, lipophilic, inorganically complexed TE species can cross biological membrane by diffusion. TEs bound to very fine particles can also be engulfed by endocytosis [57,58]. Following absorption, metals are transported to internal organs for utilization, storage, toxic effects, and possibly release [57].

TEs can further be removed from seawater through passive scavenging, i.e., the combined process of surface adsorption onto a wide variety of relatively high affinity surface sites on both living and dead particulate material followed by particle settling $[56,59,60]$. Much of this particulate material (along with its associated TEs) is recycled either in the water column or in superficial sediments. Labile bound TEs can desorb from settling particles and resupply free TE to the dissolved pool [57]. Marine sediments can also act as a source of TEs by releasing chemicals back to the overlying water column [54,61]. The primary flux processes between sediments and the water column are resuspension and deposition, bioturbation, advection, upwelling/ downwelling, diagenesis reactions, and diffusion [61]. Because of these remobilization processes, the effects of metal pollution on local environments and organisms can be substantial and long lasting in spite of years of restoration efforts [54].

\section{TE toxicity on aquatic biota}

TE metabolism and toxicity testing: The potential impact of a contaminant on aquatic biota depends on the total concentration of the contaminant, its speciation, interactions at receptors sites (e.g., at a fish gill membrane or on an algal cell surface) and uptake into the organism/cell, with either subsequent adverse effects or intracellular detoxification [62]. The toxicity of each TE will therefore be related to an organism-specific, metabolically available threshold concentration [63]. TEs accumulated into an organism occur in a bioreactive fraction that is metabolically active and available and a fraction that has been 
detoxified and is unavailable (Figure 2) [64]. TEs bound to inducible TE-binding proteins such as metallothioneins or phytochelatins or precipitated into insoluble concretions consisting of TE-rich granules are biologically detoxified; on the contrary, TEs bound to sensitive fractions such as organelles and heat-sensitive proteins can be metabolically active. The higher the proportion of TE-sensitive fractions, the greater the vulnerability to TE toxicity $[65,66]$. The TEsensitive fractions and TEs bound to metallothioneins are available for trophic transfer to predators [66]. This compartmentalization of TEs as defined by Wallace and Luoma [66] and Wallace et al. [65] is a useful tool to interpret multiple ecotoxicological consequences of the subcellular partitioning of TEs within organisms.

Mayer-Pinto et al. [67] critically reviewed studies on the effects of TEs on aquatic assemblages and/or populations of invertebrates. They pointed out that most studies in the field had been descriptive: they generally demonstrated that the diversity of an assemblage tended to decrease with an increase of environmental TE pollution and that there were differences in the structure of assemblages facing high pollution levels. Such descriptive studies are, however, unable to demonstrate any causal relationship between the environmental pollution and the changes observed [67]. Toxicity testing methods are therefore required as a tool for predicting and assessing the impacts of anthropogenic environmental stressors on organisms and ecosystems [25]. Laboratory-based toxicity testing has the obvious advantage to be unaffected by habitat or natural disturbances. This allows for experimental evaluation of various parameters and conditions such as temperature, toxicant threshold effect levels, mixture interactions, life stages or exposure duration under strictly controlled conditions [61]. Despite laboratory studies show lethal and sub-lethal effects of TEs on organisms, extrapolating such findings to the field is however little reliable [68]. Indeed, the exposure of aquatic organisms to contaminants is mostly episodic due to changing water and sediment quality. In addition, physicochemical characteristics of aquatic ecosystems (e.g., temperature, $\mathrm{pH}$, water hardness, dissolved organic carbon) greatly influence contaminant bioavailability, toxicity and bioaccumulation [69-71]. The naturally occurring variability of water and sediment properties affecting TE chemical bioavailability cannot be easily simulated in the laboratory [72]. Additional field experiments are therefore necessary to validate laboratory results under relevant environmental conditions.

Complementary results from laboratory and field toxicity tests are useful for decision making, particularly if the responses of the test organisms are severe and occur in multiple species [61]. Within this perspective, detailed reviews on tested organisms from different taxonomic groupings allow to identify species that may be suitable candidates in a suite of toxicity test protocols [73] and to highlight toxicity knowledge gaps that require to be addressed before using the retained species in routine toxicity test procedures [74]. Such a work of synthesis was performed for the Australian coastal waters [74,75]. Thus, Van Dam et al. [74] reviewed the toxicity testing methods for water column contaminants, summarizing data available for 16 taxonomic groupings, among them vascular plants (seagrasses and mangroves) and bivalve molluscs. Moreover, Adams and Stauber [75] reviewed the whole sediment toxicity tests developed with numerous species of 7 taxonomic groupings, of which bivalve molluscs. These authors reported that bivalve molluscs were particularly relevant test organisms for water and sediment toxicity tests and that seagrasses, as strong accumulator of TEs, could act as integrated markers for environmental TE exposure.

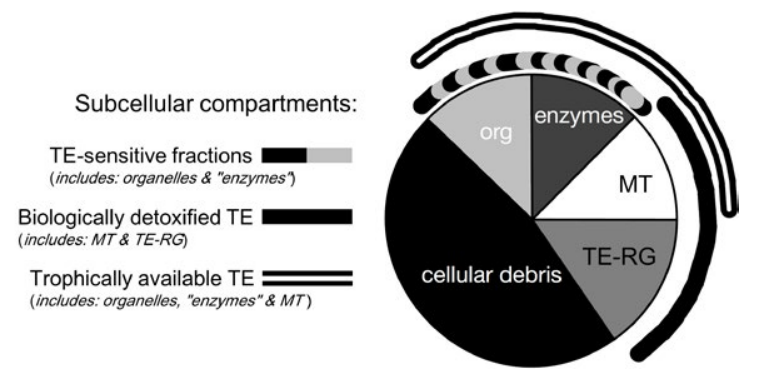

Figure 2: A generalized ecotoxicological pie chart depicting subcellular compartments based on the biological significance of the various subcellular fractions in clams. Clams were homogenized, and differential centrifugation and tissue digestion techniques were used to obtain the following subcellular fractions (detailed procedure in Ref. [66]): trace element-rich granules (TERG), cellular debris, organelles (org), heat-sensitive proteins ("enzymes") and heat-stable proteins (metallothioneins, MT). Subcellular fractions that are potentially vulnerable to TE exposure (i.e., organelles and "enzymes"; dashed arc) constitute the TE-sensitive fractions. Fractions that are involved with TE detoxification (i.e., metallothioneins and TE-rich granules; solid arc) constitute biologically detoxified TE. Fractions containing TEs that are readily available to predators (i.e., organelles, "enzymes" and metallothioneins; double arc) constitute trophically available TE (modified after Ref. [65])

TE toxic effects on bivalve molluscs: Bivalve molluscs show many physiological attributes (sensitive to contaminants, tolerant of a wide range of abiotic factors, easy to grow and maintain in a laboratory etc.) that make them appropriate bioassay organisms for toxicity testing [76]. They are moreover good accumulators of organometallic contaminants and TEs due to their behaviour and mode of feeding [77]. A number of standardized toxicity test protocols have been developed for determining toxicity of single chemicals, complex effluents and ambient samples of water or sediments to marine bivalves (e.g., Ref. [61]; detailed guidance manuals available from the US Environmental Protection Agency (EPA) and the American Society for Testing and Materials (ASTM) [78]). Toxicity tests established on bivalve embryolarval developments are among the most sensitive in the EPA's national toxicity dataset, which is used to derive water quality criteria [79]. Among bivalve molluscs, mussels from the genus Mytilus have been largely used. TE toxicity on bivalve molluscs can be determined at different structural levels, from genes to individuals, and response parameters have included, in addition to larval-embryo developments, changes in growth rates, clearance rates and survival rates, DNAdamages, or changes in tissue morphology and in specific component immunoreactivity (Table 3) [79-88].

Toxicity varies greatly between TEs. The median effect concentrations (EC50) for Meretrix meretrix embryogenesis is 188 times higher for $\mathrm{Cd}$ than for $\mathrm{Hg}$. Moreover, this difference in toxicity directly relies upon the response parameter of interest. Thus, the EC50 for M. meretrix larval growth is only 6 times higher for Cd than for $\mathrm{Hg}$ [83]. TE toxicity also fluctuates spatially and over time with water properties, as demonstrated for $\mathrm{Cu}$. The EC50 obtained by $\mathrm{Cu}$ spiking of ambient water samples for mussel embryo development was lower at sites located near the mouth of the San Diego Bay (California, USA) compared to sites at the back of that Bay. This increase was consistent with similar increasing trends in dissolved organic carbon (DOC) and total suspended solids [79]. This protective effect of DOC on $\mathrm{Cu}$ toxicity, experimentally demonstrated with contaminated filtered seawater spiked with DOC, appeared related to higher fulvic acid and lower humic acid contents [80].

TE toxic effects on seagrasses: Current knowledge on aqueous toxicity of TEs in segrasses consists mainly of single TE exposures 
Citation: Richir J, Gobert S (2016) Trace Elements in Marine Environments: Occurrence, Threats and Monitoring with Special Focus on the Coastal Mediterranean. J Environ Anal Toxicol 6: 349. doi:10.4172/2161-0525.1000349

tested on 8 species (Table 4) [89-96]. Experimental designs have varied considerably due, in part, to the lack of standardized toxicity tests for marine vascular plants contrary to bivalve molluscs. Test durations were between 6 hours and 51 days and response parameters included photosynthetic activity, amino acid concentrations, tissue growth, pigment contents or leaf cell mortality. $\mathrm{Cu}, \mathrm{Cd}, \mathrm{Pb}$, and $\mathrm{Zn}$ were the most commonly tested compounds with $\mathrm{Cu}$ toxicity being particularly high, leading to seagrass leaf necrosis and decay (e.g., Ref. $[93,96]$. Interspecific differences in sensitivity to the same TE have been reported. Prange and Dennison [91] incubated 5 seagrass species (Halophila ovalis, Halophila spinulosa, Halodule uninervis, Zostera capricorni and Cymodocea serrulata) with $\mathrm{Fe}$ or $\mathrm{Cu}$ (1 ppm); seagrass responses to pollutants were assessed by changes in PSII photochemical efficiency and free amino acid content. Fe additions only affected Halophila spp. while $\mathrm{Cu}$ additions affected the other seagrass species as well. TE sensitivities can even differ between populations of a same species. Macinnis-Ng and Ralph [94] in situ monitored the effects of $\mathrm{Cu}$ and $\mathrm{Zn}$ on 3 geographically isolated populations of $Z$. capricorni in Sydney area (Australia). Photosynthetic efficiency and chlorophyll pigment concentrations showed different sensitivities to $\mathrm{Cu}$ exposures at the 3 sites, with seagrasses from the least developed estuary being the most sensitive to $\mathrm{Cu}$.

Marine vascular plants are still rarely used in ecotoxicological testing, primarily because of difficulties in culturing/adapting and testing with such large, slow growing organisms [74]. To overcome these difficulties, and for greater environmental relevance, more recent toxicity tests involved the in situ measurement of photosynthetic endpoints (using PAM fluorometry) on wild plants in chamber experiments (e.g., Ref. $[93,94])$. Field measurements of photosynthetic efficiency can moreover be easily used as an efficient overall ecoindicator of seagrass health (e.g., Ref. [97]). In addition, phytotoxic effect levels for sediment-bound chemicals, spiked or in a whole sediment matrix, are relatively unknown for seagrasses. But because concentrations of several anthropogenic chemicals in rooted sediments exceed sediment quality guidelines, there is a need to better understand the bioavailability

\begin{tabular}{|c|c|c|c|c|c|c|c|}
\hline Species & $\begin{array}{c}\text { Studied trace } \\
\text { elements and } \\
\text { sites }\end{array}$ & $\begin{array}{l}\text { Measured } \\
\text { parameters }\end{array}$ & Test duration & $\begin{array}{l}\text { Experimented } \\
\text { concentrations }\end{array}$ & $\begin{array}{l}\text { Field or effect } \\
\text { concentrations and } \\
\text { measured effects }\end{array}$ & Supplementary comments & Ref. \\
\hline $\begin{array}{l}\text { Mytilus } \\
\text { galloprovincialis } \\
\text { (laboratory) }\end{array}$ & $\begin{array}{c}\text { water } \\
\text { exposure: Cu; } \\
\text { San Diego Bay } \\
\text { (CA, USA) }\end{array}$ & $\begin{array}{l}\text { embryo-larval } \\
\text { development }\end{array}$ & $48 \mathrm{~h}$. & $\begin{array}{l}\text { unfiltered seawater; } \\
\text { nominal tested } \\
\text { concentration range } \\
\left(\mu \mathrm{g} \mathrm{L}^{-1}\right): 0-50 ; \text { filtered } \\
\text { seawater used for } \\
\text { reference toxicant } \\
\text { tests }\end{array}$ & $\begin{array}{l}\text { absence of ambient } \\
\text { toxicity to bivalve } \\
\text { embryos; reference } \\
\text { toxicant test EC50 } \\
\text { value }=6.43 \pm 1.36 \\
\mu \mathrm{g}_{\mathrm{Cu}} \mathrm{L}^{-1} ; \mathrm{EC} 50 \text { of } \mathrm{Cu} \\
\text { spiked ambient water } \\
\text { samples: } 1.7 \text { to } 3.4 \\
\text { times lower at sites } \\
\text { located near the mouth } \\
\text { of the Bay compared } \\
\text { to sites at the back of } \\
\text { the Bay. }\end{array}$ & $\begin{array}{l}\text { Normally developed bivalve larvae } \\
\text { possess a hinged D-shaped shell } \\
\text { (prodissoconch); differences } \\
\text { bewteen unfiltered Cu spiked water } \\
\text { samples indicate a gradient in } \\
\text { complexation capacity increasing } \\
\text { from the mouth to the back of } \\
\text { the Bay (consistent with similar } \\
\text { increasing trends in DOC and TSS). }\end{array}$ & [79] \\
\hline $\begin{array}{l}\text { Mytilus trossolus } \\
\text { (laboratory) }\end{array}$ & $\begin{array}{c}\text { water } \\
\text { exposure: } \\
\mathrm{Cu}, \mathrm{Zn}, \mathrm{Ni} \text {, } \\
\mathrm{Cd} \text { (tested } \\
\text { separetely) }\end{array}$ & $\begin{array}{l}\text { embryo-larval } \\
\text { development }\end{array}$ & $48 \mathrm{~h}$. & $\begin{array}{c}\text { filtered seawater; } \\
\text { measured } \\
\text { concentration } \\
\text { ranges }\left(\mu \mathrm{g} \mathrm{L}^{-1}\right) \text { : } \\
\mathrm{Cu}=1.1-71.0 ; \mathrm{Zn}=5- \\
576 ; \mathrm{Ni}=<\mathrm{DL}-760 ; \\
\mathrm{Cd}=<\mathrm{DL}-1,200 ; \text { effect } \\
\text { of } \mathrm{DOC} \text { addition on } \\
\text { metal toxicity tested } \\
\text { for } \mathrm{Cu}\end{array}$ & $\begin{array}{c}\mathrm{EC} 50 \text { (in } \mu \mathrm{g} \mathrm{L}^{-1} \text { ): } 9.6 \\
\text { for } \mathrm{Cu}, 99 \text { for } \mathrm{Zn}, 150 \\
\text { for } \mathrm{Ni} \text {, and } 502 \text { for } \mathrm{Cd} \text {; } \\
\text { experimental addition } \\
\text { of } \mathrm{DOC} \text { reduced } \mathrm{Cu} \\
\text { toxicity. }\end{array}$ & $\begin{array}{l}\text { Normally developed bivalve larvae } \\
\text { possess a hinged D-shaped } \\
\text { shell (prodissoconch); protective } \\
\text { effects of DOC on Cu toxicity } \\
\text { are influenced by their distinct } \\
\text { physicochemical properties: } \\
\text { protection appears to be related to } \\
\text { higher fulvic acid and lower humic } \\
\text { acid contents. }\end{array}$ & [80] \\
\hline $\begin{array}{l}\text { Mytilus } \\
\text { galloprovincialis } \\
\text { (laboratory) }\end{array}$ & $\begin{array}{c}\text { water } \\
\text { exposure: } \mathrm{Cr}\end{array}$ & $\begin{array}{l}\text { gill morphology and } \\
\text { immunoreactivity to } \\
\text { components involved } \\
\text { in gill motility; total } \\
\text { glutathione content; } \\
\text { activities of GSH- } \\
\text { related enzymes, of } \\
\text { catalase, and of key } \\
\text { glycolytic enzymes; } \\
\text { mRNA expression of } \\
\text { selected genes }\end{array}$ & $96 \mathrm{~h}$. & $\begin{array}{c}\text { artificial seawater; } \\
\text { nominal tested } \\
\text { concentrations }(\mu \mathrm{g} \\
\left.\mathrm{L}^{-1}\right): 0.1,1,10\end{array}$ & $\begin{array}{c}\text { Morphological, } \\
\text { biochemical and } \\
\text { molecular changes } \\
\text { in mussel gills } \\
\text { when exposed to } \\
\text { concentrations ranging } \\
\text { from } 0.1 \text { to } 10 \mu \mathrm{g} \mathrm{L}^{-1} \text {. }\end{array}$ & \begin{tabular}{|} 
Progressive changes in \\
gill morphology and in \\
immunoreactivity to components \\
involved in neurotransmission; \\
increased activities of GSH-related \\
enzymes and total glutathione \\
content suggesting Cr detoxication/ \\
reduction at the site of metal entry; \\
increased activity of glycolytic \\
enzymes, indicating modulation \\
of carbohydrate metabolism; \\
significant changes in transcription \\
of different genes (sex- and \\
concentration-related differences).
\end{tabular} & [81] \\
\hline $\begin{array}{l}\text { Mytilus edulis } \\
\text { (laboratory) }\end{array}$ & $\begin{array}{c}\text { water } \\
\text { exposure: } \mathrm{Ni}\end{array}$ & $\begin{array}{l}\text { clearance rate; } \\
\text { haemolymph } \\
\text { genotoxicity and } \\
\text { cytotoxicity }\end{array}$ & $120 \mathrm{~h}$. & $\begin{array}{c}\text { filtered seawater; } \\
\text { nominal tested } \\
\text { concentrations }(\mu \mathrm{g} \\
\left.\mathrm{L}^{-1}\right): 4.6 \text { (control), } 18 \\
56,180\end{array}$ & $\begin{array}{c}56 \mu \mathrm{g} \mathrm{L}^{-1}: \text { clearance } \\
\text { rate decreases; } 180 \\
\mu \mathrm{L} \mathrm{L} \mathrm{L}^{-1}: \mathrm{NRR} \text { decreases } \\
\text { and \% tail DNA } \\
\text { increases in mussel } \\
\text { haemocytes. }\end{array}$ & $\begin{array}{l}\text { Clearance rate is Ni concentration- } \\
\text { dependent (decreased by } 30 \% \text { at } \\
\text { the highest concentration); NRR } \\
\text { assays, designed to assess the } \\
\text { viability of the cells based on the } \\
\text { penetration of a weakly cationic } \\
\text { dye across lysosomal membranes, } \\
\text { indicate a cytotoxic response; } \\
\text { Ni has a genotoxic effect on the } \\
\text { integrity of the DNA in haemocytes. }\end{array}$ & [82] \\
\hline
\end{tabular}


Citation: Richir J, Gobert S (2016) Trace Elements in Marine Environments: Occurrence, Threats and Monitoring with Special Focus on the Coastal Mediterranean. J Environ Anal Toxicol 6: 349. doi:10.4172/2161-0525.1000349

Page 7 of 19

\begin{tabular}{|c|c|c|c|c|c|c|c|}
\hline $\begin{array}{l}\text { Meretrix meretrix } \\
\text { (laboratory) }\end{array}$ & $\begin{array}{c}\text { water } \\
\text { exposure: } \mathrm{Cd} \text {, } \\
\mathrm{Pb}, \mathrm{Hg} \text { (tested } \\
\text { separately) }\end{array}$ & $\begin{array}{l}\text { embryogenesis; } \\
\text { survival, growth and } \\
\text { metamorphosis of } \\
\text { larvae }\end{array}$ & $\begin{array}{c}24 \text { h.: } \\
\text { embryogenesis; } 48 \\
\text { h.: metamorphosis; } \\
96 \text { h.: growth and } \\
\text { survival }\end{array}$ & $\begin{array}{c}\begin{array}{c}\text { unfiltered seawater; } \\
\text { measured }\end{array} \\
\text { concentration ranges } \\
\left(\mu \mathrm{L}^{-1}\right): \mathrm{Hg}=2- \\
17,977 ; \mathrm{Cd}=1-10,167 \\
\mathrm{~Pb}=2-7,158\end{array}$ & $\begin{array}{l}\text { EC50 for } \\
\text { embryogenesis }\left(\mu g \mathrm{~L}^{-1}\right) \text { : } \\
5.4 \text { for } \mathrm{Hg}, 1,014 \text { for } \\
\text { Cd and } 297 \text { for } \mathrm{Pb} ; 96 \\
\text { h. LC50 for } \mathrm{D} \text {-shaped } \\
\text { larvae }\left(\mu \mathrm{g} \mathrm{L} \mathrm{L}^{-1}\right): 14 \text { for } \\
\mathrm{Hg}, 68 \text { for } \mathrm{Cd} \text { and } \\
353 \text { for } \mathrm{Pb} \text {; growth } \\
\text { retardment }\left(\mu \mathrm{L}^{-1}\right) \text { : } \\
18.5 \text { for } \mathrm{Hg}, 104 \text { for } \mathrm{Cd} \\
\text { and } 197 \text { for } \mathrm{Pb} \text {; EC50 } \\
\text { for metamorphosis: } \\
\text { similar to } 48 \mathrm{~h} \text {. LC50; } \\
\text { higher than } 96 \text { h. LC50. }\end{array}$ & $\begin{array}{l}\text { Embryo toxicity: the \% of normal } \\
\text { D-shaped larvae decreases when } \\
\mathrm{Hg}, \mathrm{Cd} \text { and } \mathrm{Pb} \text { concentrations } \\
\text { increase. Larval growth: dead } \\
\text { larvae with extruded velum and } \\
\text { granulated tissues in the more } \\
\text { toxic treatments; injury to the } \\
\text { velum and swimming inhibition at } \\
\text { lower concentrations; reduction } \\
\text { in growth rate following exposure } \\
\text { to most concentrations from } 24 \\
\text { h. Concentration-dependent } \\
\text { survival inhibition of larvae. Hg } \\
\text { most toxic and Pb least toxic to } \\
\text { metamorphosing larvae. }\end{array}$ & [83] \\
\hline $\begin{array}{l}\text { Tellina } \\
\text { deltoidalis } \\
\text { (laboratory) }\end{array}$ & $\begin{array}{l}\text { metal spiked } \\
\text { sediment } \\
\text { exposure: } \mathrm{Cd} \text {, } \\
\mathrm{Cu}, \mathrm{Ni}, \mathrm{Pb} \text {, } \\
\mathrm{Zn} \text { (tested } \\
\text { separetely); } \\
\text { water } \\
\text { exposure: } \mathrm{Cu} \\
\text { and } \mathrm{Zn} \text { (tested } \\
\text { separetely) }\end{array}$ & survival rate & $10 \mathrm{~d}$ & $\begin{array}{c}\text { nominal metal } \\
\text { concentrations in } \\
\text { sediment tests (mg } \\
\left.\mathrm{kg}^{-1}\right): 75,1,300,420 \\
1,000 \text { and } 4,000 \text { for } \\
\mathrm{Cd}, \mathrm{Cu}, \mathrm{Ni}, \mathrm{Pb} \text {, and } \\
\mathrm{Zn} \text {, respectively; } \\
\text { measured metal } \\
\text { ranges in seawater } \\
\text { tests: } 0-710 \mathrm{\mu g} \mathrm{L}^{-1} \text { for } \\
\text { Cu; } 0-13 \mathrm{mg} \mathrm{L}^{-1} \text { for } \mathrm{Zn}\end{array}$ & $\begin{array}{l}\text { Sediment exposure: } \\
\text { absence of toxicity. } \\
\text { Water exposures: at } \\
\text { Cu concentrations of } \\
50 \text { and } 200 \mu \mathrm{g} \mathrm{L}^{-1} \text {, time } \\
\text { to LC50=7 d. and } 5 \\
\text { d., respectively; at } \mathrm{Cu} \\
\text { concentration of } 13 \mathrm{mg} \\
\mathrm{L}^{-1} \text {, time to LC50 } 4 \mathrm{~d} \text {. }\end{array}$ & $\begin{array}{l}\text { Survival to metal spiked sediments: } \\
88-100 \% \text {; the absence of toxicity } \\
\text { is consistent with the low sensitivity } \\
\text { of } T \text {. deltoidalis to these metals in } \\
\text { the dissolved intertidal phase and } \\
\text { indicated that the exposure from } \\
\text { the ingestion of metal-contaminated } \\
\text { particles was not sufficient to } \\
\text { cause toxicity over the } 10 \text {-days } \\
\text { period. Survival to water exposure: } \\
\text { concentration-dependent survival; } \\
\text { Cu toxicity higher than Zn toxicity. }\end{array}$ & [84] \\
\hline $\begin{array}{l}\text { Mytilus } \\
\text { galloprovincialis } \\
\text { (field) }\end{array}$ & $\begin{array}{l}\text { sediment } \\
\text { exposure: } \mathrm{Ni} \text {; } \\
\text { Kaštela and } \\
\text { Trogir Bays } \\
\text { (Croatia) }\end{array}$ & $\begin{array}{l}\text { MN test (toxin induced } \\
\text { heightened MN } \\
\text { frequency) and Comet } \\
\text { assay (tail DNA) with } \\
\text { mussel haemocytes }\end{array}$ & $30 \mathrm{~d}$. & na & $\begin{array}{l}\text { Ni range in sediments: } \\
\quad 48-420 \mu \mathrm{g} \mathrm{g}^{-1}\end{array}$ & $\begin{array}{l}\text { Increased } \% \text { of MN (defined as } \\
\text { small round structures in the } \\
\text { cytoplasm smaller than } 1 / 3 \text { of } \\
\text { the nucleus diameter) compared } \\
\text { to mussels from the reference } \\
\text { location evident for most of the } \\
\text { contaminated locations; increase } \\
\text { in the } \% \text { of tail DNA in individuals } \\
\text { collected from mostly all the } \\
\text { polluted sites; the } 2 \text { methods } \\
\text { complement each other and it } \\
\text { is desirable to use them both in } \\
\text { monitoring the impacts of genotoxic } \\
\text { pollution. }\end{array}$ & [85] \\
\hline $\begin{array}{l}\text { Mytilus spp. } \\
\text { (field) }\end{array}$ & $\begin{array}{l}\text { sediment } \\
\text { elutriate } \\
\text { (water soluble } \\
\text { fraction) } \\
\text { exposure: } \mathrm{Zn} \text {, } \\
\mathrm{Ni}, \mathrm{Cr}, \mathrm{Cu}, \mathrm{As} \text {, } \\
\mathrm{Pb}, \mathrm{Hg}, \mathrm{Ag}, \\
\mathrm{Cd}, \mathrm{Se} \text {; San } \\
\text { Fransisco Bay } \\
\text { (USA) }\end{array}$ & $\begin{array}{c}\% \text { normal larval } \\
\text { development }\end{array}$ & $48 \mathrm{~h}$. & na & $\begin{array}{l}\text { Sediment quality } \\
\text { guidelines used to } \\
\text { evaluate the potential } \\
\text { toxicity of sediments: } \\
\text { concentrations < ERL, } \\
\text { between the ERL } \\
\text { and ERM or }>\text { ERM } \\
\text { are rarely }(<11 \%), \\
\text { occasionally }(16-18 \%) \\
\text { or frequently }(48-52 \%) \\
\text { associated with toxicity, } \\
\text { respectively; Ni usually } \\
\text { above the ERM; As, } \\
\text { Cr, Cu and Hg often } \\
\text { exceed their respective } \\
\text { ERLs. }\end{array}$ & $\begin{array}{l}\text { Sediment elutriate toxicity varied } \\
\text { spatially (decreasing from sites } \\
\text { located at the back of the Bay } \\
\text { near } 2 \text { main river mouths - no } \\
\text { survival of mussel larvae - to sites } \\
\text { located near the Bay entrance - no } \\
\text { toxicity); no signicant trends in } \\
\text { larval development over time at } \\
\text { most sites; larval bivalve toxicity } \\
\text { was associated with metals in bulk } \\
\text { sediments. }\end{array}$ & $\begin{array}{l}{[86,} \\
87]\end{array}$ \\
\hline $\begin{array}{l}\text { Mytilus trossulus } \\
\text { (field) }\end{array}$ & $\begin{array}{l}\text { sediment } \\
\text { exposure: As, } \\
\text { Cr, } \mathrm{Cu}, \mathrm{Pb} \\
\mathrm{Hg}, \mathrm{Zn}, \mathrm{Sn}_{\mathrm{TBT}} \\
\text { Puget Sound } \\
\text { (WA, USA) }\end{array}$ & $\begin{array}{l}\text { juvenile mussel } \\
\text { growth rate }\end{array}$ & $82 \mathrm{~d}$ & na & $\begin{array}{c}\text { Trace element ranges } \\
\text { in sediments }\left(\mu \mathrm{g} \mathrm{g}{ }^{-1}\right): \\
\text { As: } 8-57 ; \mathrm{Cr}: 44-93 ; \\
\mathrm{Cu}: 66-965 ; \mathrm{Pb}: 22- \\
\text { 297; } \mathrm{Hg}: 0.13-1.95 ; \mathrm{Zn}: \\
\text { 107-592; } \mathrm{Sn}_{\mathrm{TBT}}: 0.18- \\
18.41 .\end{array}$ & $\begin{array}{l}\text { In contaminated sites, mussels } \\
\text { had lower growth rates than } \\
\text { the reference site mussels; } \\
\mathrm{Sn}_{\mathrm{TBT}} \text { and } \mathrm{Cu} \text { : contaminants of } \\
\text { greatest concern; } \mathrm{Pb} \text { and } \mathrm{Zn} \text { : } \\
\text { contaminant of additional concern; } \\
\text { statistically significant inverse } \\
\text { relationship between growth rate } \\
\text { and toxicity-normalized sediment } \\
\text { contamination. }\end{array}$ & [88] \\
\hline
\end{tabular}

Table 3: Biological responses in bivalves exposed to dissolved and sediment trace elements under laboratory or field conditions. h.: hour; d.: day; na: not applicable; EC50: the median effect concentration; LC50: the median lethal concentration; DOC: dissolved organic carbon; TSS: total suspended solids; DL: detection limit; Glutathione (GSH)-related enzymes; NRR: neutral red retention; MN: micronucleus; ERL: effects range-low; ERM: effects range-median. 
and phytotoxicity of sediment-bound contaminants [72].

\section{The monitoring of the marine environment}

Biomonitoring: Until the early 70 s, the monitoring of terrestrial and marine environments mainly relied on the detection and quantification of pollutants in physical environments - air, water, soils and sediments $[25,98]$. During the years 80 s, almost all environmental monitoring networks stopped monitoring the water itself to assess the quality of aquatic ecosystems. Reasons for this abandon were diverse, among them: the measured concentrations of chemicals are generally low (in the order of a few ng $\mathrm{L}_{\text {water }}^{-1}$ for most TEs) and often close to the limits of detection of the analytical techniques; the risk of secondary accidental contamination makes the measurements sensitive; the concentrations of dissolved substances may vary considerably over time (e.g., with tidal cycles, water run-off, seasons etc.) and episodic pollution events can be missed; the measurement of dissolved pollutants do not provide an assessment of the portion which is available for uptake and accumulation by aquatic organisms $[25,99]$. The analysis of sediments overcomes some of these disadvantages. Contaminants accumulated in sediments, particularly in organically rich sediments, are more easy to monitor and much less susceptible to accidental contaminations. Sediments also offer a degree of time integration. However, sediment accumulation of contaminants is much affected by sediment characteristics (particle size, mineralogy, organic carbon content) and measured-concentrations again do not provide an assessment of their bioavailable fractions [25,99].

When compared with the conventional chemical analysis of water and sediments, the monitoring relying upon the biota exhibits obvious predominance. Biomonitoring reveals the biological changes of organisms affected by chemicals and the integrated effects of multiple pollutants on these latest; has high sensitivity because of the rapid responses induced in organisms exposed to pollutants; realizes the monitoring of pollutants at low levels because of their chronic toxicities under long-term exposure; allows widely sampling even at remote areas; avoids the limits of the conventionnal chemical analysis such as continuous sampling, needs of expensive instruments etc. [100].

Bioindicators: Since the ultimate purpose of pollution monitoring is the protection of ecosystems and human beings, the main interest of the use of quantitative sentinel organisms with regard to water or sediments is their capacity to give information on the bioavailability of pollutants [101]. Currently, the term "bioindicator" is a deeply ambiguous term which has different meanings in different contexts [102]. To prevent problems due to different interpretations of this term, we use the definition of Blandin [103]: "a biological indicator (or bioindicator) is an organism or a set of organisms that allows, by reference to biochemical, cytological, physiological, ecological or ethological variables, in a practical and safe way, to characterise the status of an ecosystem or an eco-complex and to highlight as early as possible their changes, natural or caused". Bioindicators therefore allow to accurately assess the effects of anthropogenic activities on ecosystems.

To be considered as a good bioindicator of environmental contamination, the selected species must meet a number of criteria, as listed by Cossa [101] or Rainbow [104]: the sentinel organism should be a net strong accumulators of contaminants and should not regulate the total concentration of a contaminant in its body tissues; it should be sedentary and reasonably abundant; it should have a sufficiently long life to permit sampling of more than one-year class; it should be large enough to provide sufficient tissue for analyses and should bioaccumulate sufficiently to allow direct measurement without preconcentration; it should be resistant to handling stresses; a correlation should exist between the level of contaminants in the organism and in the surrounding environment; it should be tolerant of exposure to environmental variations in physicochemical parameters and the effects on the organism of these variations should be known. No single species however combines all these qualities, and a compromise must be found [101].

For marine pollution monitoring, the bioindicator species used belong to numerous taxonomic groupings of which micro- and macro-algae, seagrasses, ascidians, sponges, bivalve and gastropod molluscs, polychetes, crustaceans, fishes, seabirds, marine reptiles and mammals [105,106], each bioindicator showing some special merits when compared to the others [100]. In the two next sections, we will present two bioindicator species widely used in the monitoring of the health status of the coastal Mediterranean, from punctual surveys to international monitoring programs: the Neptune grass Posidonia oceanica and the Mediterranean mussel Mytilus galloprovincialis. These two bioindicators respond appreciably and quantitatively to the coastal pollution by TEs and complement one another: the two species accumulate contaminants dissolved in the water column; $P$. oceanica, deeply rooted in sediments, also reflects the contamination of this compartment; mussels, as a filter feeder, accumulate contaminants from their particulate phase. Together, they give an estimate of the overall pollution (water, sediments, suspended matter) of Mediterranean coastal environments [107].

\section{Posidonia oceanica}

\section{Biology}

$P$. oceanica is a marine magnoliophyte endemic to the Mediterranean $[108,109]$. It grows on sandy and rocky bottoms and forms patchy and continuous meadows regarded as one of the climax communities of the Mediterranean [110]. It colonizes large areas of the infralittoral floor from the surface to maximal depths of $45 \mathrm{~m}[110,111]$. $P$. oceanica beds cover a surface estimated between 25,000 and 50,000 $\mathrm{km}^{2}$, i.e., between 1 and $2 \%$ of the Mediterranean [112], and is only missing in zones under the influence of large estuaries (Po, Rhone, Nile - diminution of salinity and increase of turbidity) [113]. The light and the transparency of the water are determining factors for its growth [114]. P. oceanica has the same morphology as the other marine magnoliophytes: below-ground parts consist of roots for anchoring and rhizomes for mechanical support; above-ground parts consist of shoots bearing several leaves [115]. Rhizomes grow horizontally (competition for space: plagiotropic rhizome) or vertically (competition for access to the light: orthotropic rhizome). The progressive silting and the two types of rhizome growth result in a typical terraced formation called "matte" consisting of the intertwining of various strata of rhizomes, roots, and sediments [113].

P. oceanica plays various ecological and functional roles (reviewed in Ref. $[12,16,116])$. First of all, P. oceanica meadows are considered to be among the most productive ecosystems of our planet. This ecosystem is made up by the juxtaposition of two types of primary production: the net primary production of $P$. oceanica which is on average of $420 \mathrm{~g}_{\mathrm{DM}} \mathrm{m}^{-2}$ year ${ }^{-1}$ and can reach $1,300 \mathrm{~g}_{\mathrm{DM}} \mathrm{m}^{-2}$ year-1; the net primary production of the epiphytes which is between 100 and 500 $g_{D M} m^{-2}$ year ${ }^{-1}$. On a global scale, only seagrass ecosytems display this specific feature. $P$. oceanica exhibits structural roles: $P$. oceanica leaf canopy acts as a sediment trap; $P$. oceanica meadows reduce the coastal erosion and stabilize coastlines through direct effect on wave motion 
Citation: Richir J, Gobert S (2016) Trace Elements in Marine Environments: Occurrence, Threats and Monitoring with Special Focus on the Coastal Mediterranean. J Environ Anal Toxicol 6: 349. doi:10.4172/2161-0525.1000349

Page 9 of 19

\begin{tabular}{|c|c|c|c|c|c|c|c|}
\hline Species & $\begin{array}{l}\text { Studied trace } \\
\text { elements and } \\
\text { sites }\end{array}$ & $\begin{array}{l}\text { Measured } \\
\text { parameters }\end{array}$ & $\begin{array}{c}\text { Test } \\
\text { duration }\end{array}$ & $\begin{array}{l}\text { Experimented } \\
\text { concentrations }\end{array}$ & $\begin{array}{l}\text { Effect concentrations and } \\
\text { measured effects }\end{array}$ & Supplementary comments & Ref. \\
\hline $\begin{array}{l}\text { Zostera marina } \\
\text { (laboratory) }\end{array}$ & $\begin{array}{l}\mathrm{Cu}, \mathrm{Cr}, \mathrm{Cd} \text {, } \\
\mathrm{Hg}, \mathrm{Zn}, \\
\mathrm{Pb} \text { (tested } \\
\text { separetely) }\end{array}$ & growth rate & $\begin{array}{l}0.5,2,5 \\
8,12 \text { and } \\
19 \mathrm{~d} .\end{array}$ & $\begin{array}{c}0.1,0.5,5 \text { and } \\
50 \mu \mathrm{M}\end{array}$ & $\begin{array}{l}\text { Growth rate inhibition - Cd: after } \\
12 \mathrm{~d} \text {. at } 5 \mu \mathrm{M} \text { and after } 8 \mathrm{~d} \text {. at } 50 \\
\mu \mathrm{M} \text {; Cu: after } 5 \mathrm{~d} \text {. at } 5 \mu \mathrm{M} \text { and } \\
\text { after } 2 \mathrm{~d} \text {. at } 50 \mu \mathrm{M} ; \mathrm{Hg} \text { : rapid } \\
\text { effect at all concentrations; } \mathrm{Zn} \text { : } \\
\text { after } 2 \mathrm{~d} \text {. at } 50 \mu \mathrm{M} \text {. }\end{array}$ & $\begin{array}{c}\text { Growth rate inhibited by } \mathrm{Cd}, \mathrm{Cu}, \mathrm{Hg} \text {, } \\
\mathrm{Zn} \text {; no effect of } \mathrm{Cr} \text { and } \mathrm{Pb} \text { exposures; } \\
\text { toxicity of metals decreases in the } \\
\text { order: } \mathrm{Hg} \geq \mathrm{Cu}>\mathrm{Cd} \geq \mathrm{Zn}>\mathrm{Cr} \text { and } \mathrm{Pb} \text {; } \\
\text { cellular substances are leached to the } \\
\text { water and plants turned black in the } \\
\text { Cu } 50 \mu \mathrm{M} \text { experiment and in the } \mathrm{Hg} 5 \\
\mu \mathrm{M} \text { and } 50 \mu \mathrm{M} \text { experiments. }\end{array}$ & [89] \\
\hline $\begin{array}{l}\text { Halophila } \\
\text { stipulacea } \\
\text { (laboratory) }\end{array}$ & $\mathrm{Al}$ & leaf cell viability & $12 \mathrm{~d}$ & $\begin{array}{l}\text { from } 10^{-4} \text { to } 10^{-9} \\
\mathrm{~mol} \mathrm{~L}^{-1}\end{array}$ & $\begin{array}{l}\text { Cellular damages from } 10^{-4} \text { to } 10^{-8} \\
\mathrm{~mol} \mathrm{~L}^{-1} \text {. }\end{array}$ & $\begin{array}{l}\text { Protoplast necrosis in all cell } \\
\text { categories (except in the mid-rib } \\
\text { cells); plasmatic resistance decreases } \\
\text { in the order mid-rib, mesophyl, } \\
\text { epidermal, teeth cells. }\end{array}$ & [90] \\
\hline $\begin{array}{l}\text { Halophila ovalis, } \\
\text { Halophila } \\
\text { spinulosa, } \\
\text { Halodule } \\
\text { uninervis, } \\
\text { Zostera } \\
\text { capricorni and } \\
\text { Cymodocea } \\
\text { serrulata } \\
\text { (laboratory) }\end{array}$ & $\begin{array}{c}\text { Fe, Cu (tested } \\
\text { separetely) }\end{array}$ & $\begin{array}{l}\text { changes in PSII } \\
\text { photochemical } \\
\text { efficiency (Fv/Fm) } \\
\text { and free amino acid } \\
\text { content }\end{array}$ & $\begin{array}{l}12 \mathrm{~d} \text {. of } \\
\text { exposure; } \\
5 \mathrm{~d} \text {. of } \\
\text { recovery }\end{array}$ & $1 \mathrm{mg} \mathrm{L}^{-1}+$ EDTA & $\begin{array}{l}\text { Fe and } \mathrm{Cu}: 1 \mathrm{mg} \mathrm{L}^{-1} \text {; decline in } \\
\text { PSIl photochemical efficiency and } \\
\text { in amino acid contents; effects } \\
\text { are species-specific. }\end{array}$ & $\begin{array}{l}\text { Fe addition experiments: declines in } \\
\text { PSII photochemical efficiency in } H \text {. } \\
\text { ovalis and } H \text {. spinulosa correspond } \\
\text { with the replacement of fresh } \\
\text { seawater (12 days), suggesting that } \\
\text { these species became acclimatized } \\
\text { to the new environmental conditions; } \\
Z \text {. capricorni exhibited a decline in } \\
\text { total free amino acid contents (could } \\
\text { be a precursor signal of Fe induced } \\
\text { stress). Cu addition experiments: Fv/ } \\
\text { Fm ratio response was highly variable } \\
\text { between the } 5 \text { seagrass species } \\
\text { (death of } H \text {. spinulosa); decline in } \\
\text { amino acid concentrations in } Z \text {. } \\
\text { capricorni and } H \text {. uninervis. }\end{array}$ & [91] \\
\hline $\begin{array}{l}\text { Halophila ovalis } \\
\text { (laboratory) }\end{array}$ & $\begin{array}{l}\mathrm{Cu}, \mathrm{Cd}, \mathrm{Pb} \text {, } \\
\mathrm{Zn} \text { (tested } \\
\text { separately) }\end{array}$ & $\begin{array}{c}\text { chlorophyll } a \\
\text { fluorescence; } \\
\text { pigments (chlorophyll } \\
a, b \text {, and carotenoids) }\end{array}$ & $4 \mathrm{~d}$ & 1,5 and $10 \mathrm{mg} \mathrm{L}^{-1}$ & $\begin{array}{l}\text { Cd - } 1 \text { to } 10 \mathrm{mg} \mathrm{L}^{-1} \text { : limited stress. } \\
\mathrm{Cu}-5 \text { to } 10 \text { and } 10 \mathrm{mg} \mathrm{L}^{-1}: \\
\text { lethal effect. } \mathrm{Pb}-1 \text { to } 10 \mathrm{mg} \mathrm{L}^{-1} \text { : } \\
\text { limited effect on fluorescence; } \\
\text { chl. } a, b \text { decrease. } \mathrm{Zn} \mathrm{-} 1 \text { to } 10 \\
\text { mg } \mathrm{L}^{-1}: \text { changes to the chl. } a \\
\text { fluorescence responses; various } \\
\text { effects on pigment contents. }\end{array}$ & $\begin{array}{l}\text { Variety of effects on the } \\
\text { photosynthetic processes, with } \\
\mathrm{Cu} \text { and } \mathrm{Zn} \text { having greater effects } \\
\text { than } \mathrm{Pb} \text { and } \mathrm{Cd} \text {; quantum yield is } \\
\text { the most sensitive measure of the } \\
\text { photosynthetic processes; pigment } \\
\text { contents generally confirm the } \\
\text { chlorophyll a fluorescence responses. }\end{array}$ & [92] \\
\hline $\begin{array}{c}\text { Zostera } \\
\text { capricorni (field) }\end{array}$ & $\begin{array}{l}\mathrm{Cd}, \mathrm{Cu}, \mathrm{Pb}, \\
\mathrm{Zn} \text { (tested } \\
\text { separetely); } \\
1 \text { reasonably } \\
\text { pristine site } \\
\text { at Pittwater } \\
\text { (NSW, } \\
\text { Australia) }\end{array}$ & $\begin{array}{c}\text { photosynthetic } \\
\text { efficiency }\left(\Delta \mathrm{F} / \mathrm{Fm}^{\prime}\right) \\
\text { pigments (chlorophyll } \\
a, b \text {, and carotenoids) }\end{array}$ & $\begin{array}{l}10 \mathrm{~h} \text {. of } \\
\text { exposure; } \\
3 \mathrm{~d} \text {. of } \\
\text { recovery }\end{array}$ & 0.1 and $1 \mathrm{mg} \mathrm{L}^{-1}$ & $\begin{array}{c}\mathrm{Cu}, \mathrm{Zn}-0.1 \text { and } 1 \mathrm{mg} \mathrm{L}^{-1} \text { : } \\
\text { photosynthetic efficiency } \\
\text { decreases during the exposure } \\
\text { period; } \mathrm{Cu}-0.1 \text { and } 1 \mathrm{mg} \mathrm{L}^{-1} \text { : } \\
\text { after } 96 \mathrm{~h} \text {., carotenoid pigments } \\
\text { decline, the chlorophyll alb ratio } \\
\text { is depressed and the chlorophyll/ } \\
\text { carotenoid ratio is elevated. }\end{array}$ & $\begin{array}{l}\text { Samples exposed to } \mathrm{Zn} \text { recover } \\
\text { to pre-exposure levels but those } \\
\text { exposed to } \mathrm{Cu} \text { do not; browning of } \\
\text { leaves and some leaf loss occurred } \\
\text { due to exposure to } \mathrm{Cu} \text {; } \mathrm{Cd} \text { and } \mathrm{Pb} \text { do } \\
\text { not have impact on the chlorophyll a } \\
\text { fluorescence and the pigment data } \\
\text { support these findings. }\end{array}$ & [93] \\
\hline $\begin{array}{c}3 \text { isolated } \\
\text { populations } \\
\text { of Zostera } \\
\text { capricorni (field) }\end{array}$ & $\begin{array}{l}\text { Cu, Zn (tested } \\
\text { separetely); } \\
1 \text { semi- } \\
\text { pristine and } \\
2 \text { impacted } \\
\text { sites in } \\
\text { Sydney area } \\
\text { (Australia) }\end{array}$ & $\begin{array}{c}\text { photosynthetic } \\
\text { efficiency }(\Delta \mathrm{F} / \mathrm{Fm} \text { '); } \\
\text { pigments (chlorophyll } \\
a, b \text {, and carotenoids) }\end{array}$ & $\begin{array}{l}10 \mathrm{~h} \text {. of } \\
\text { exposure; } \\
3 \mathrm{~d} \text {. of } \\
\text { recovery }\end{array}$ & 0.1 and $1 \mathrm{mg} \mathrm{L}^{-1}$ & $\begin{array}{c}\mathrm{Cu} \text { in the semi-pristine site }-0.1 \\
\mathrm{mg} \mathrm{L}^{-1}: \text { fluorescence decreases; } 1 \\
\mathrm{mg} \mathrm{L^{-1 }}: \text { chlorophyll concentration } \\
\text { decreases. Cu in the } 2 \text { impacted } \\
\text { sites - } 1 \mathrm{mg} \mathrm{L}^{-1} \text { : fluorescence } \\
\text { decreases. }\end{array}$ & $\begin{array}{l}\text { Lack of response due to } \mathrm{Zn} \text { exposure; } \\
\text { different sensitivities to } \mathrm{Cu} \text { : greater } \\
\text { impact of } \mathrm{Cu} \text { on the more naïve } \\
\text { population (higher decrease of } \\
\text { fluorescence during exposure and } \\
\text { lower recovery). }\end{array}$ & [94] \\
\hline
\end{tabular}




\begin{tabular}{|c|c|c|c|c|c|c|c|}
\hline $\begin{array}{l}\text { Posidonia } \\
\text { oceanica } \\
\text { (laboratory) }\end{array}$ & $\mathrm{Cd}$ & \begin{tabular}{|} 
DNA methylation \\
and chromatin \\
reconfiguration; \\
expression of PoMT2k \\
and PoCMT1; \\
nuclear chromatin \\
ultrastructure
\end{tabular} & $\begin{array}{c}6 \text { h., } 2 \text { d., } \\
4 \text { d. }\end{array}$ & 10 and $50 \mu \mathrm{M}$ & $\begin{array}{l}\text { PoMT2k expression - Cd } 50 \mu \mathrm{M} \text { : } \\
\text { increase in PoMT2k expression } \\
\text { after } 6 \mathrm{~h} \text {. in apical tips and } \\
\text { leaves; Cd } 10 \mu \mathrm{M} \text { : increase } \\
\text { in PoMT2k expression after } 2 \\
\text { d. in leaves. Changes in DNA } \\
\text { methylation and in PoCMT1 } \\
\text { expression: Cd } 10 \mu \mathrm{M} \text { after } 6 \mathrm{~h} \text {. } \\
\text { Chromatin reconfiguration: Cd } 50 \\
\mu \mathrm{M} \text { after } 2 \mathrm{~d} \text {. }\end{array}$ & $\begin{array}{l}\text { Cd treatment induces a DNA } \\
\text { hypermethylation (time- and } \\
\text { dose-dependent) as well as an up- } \\
\text { regulation of CMT, indicating that } \\
\text { de novo methylation occurs; a high } \\
\text { dose of Cd leads to a progressive } \\
\text { heterochromatinization of interphase } \\
\text { nuclei and apoptotic figures are } \\
\text { observed after long-term treatment; } \\
\text { Cd perturbs the DNA methylation } \\
\text { status through the involvement } \\
\text { of a specific methyltransferase; } \\
\text { such changes are linked to nuclear } \\
\text { chromatin reconfiguration likely } \\
\text { to establish a new balance of } \\
\text { expressed/repressed chromatin; the } \\
\text { data show an epigenetic basis to the } \\
\text { mechanism underlying Cd toxicity in } \\
\text { plants. }\end{array}$ & [95] \\
\hline $\begin{array}{l}\text { Halophila ovalis } \\
\text { (laboratory) }\end{array}$ & $\begin{array}{c}\mathrm{Pb}, \mathrm{Cu} \text { (tested } \\
\text { separetely) }\end{array}$ & $\begin{array}{c}\text { growth rate; leaf } \\
\text { fluctuating asymmetry } \\
\text { and dimension }\end{array}$ & $51 \mathrm{~d}$. & $\begin{array}{c}\mathrm{Pb}: 10 \text { and } 50 \mathrm{mg} \\
\mathrm{L}^{-1} ; \mathrm{Cu}: 0.5,2 \text { and } \\
4 \mathrm{mg} \mathrm{L}^{-1}\end{array}$ & $\begin{array}{l}\text { Growth rate decrease - Cu: } 0.5 \\
\mathrm{mg} \mathrm{L}^{-1} ; \mathrm{Pb}: 10 \mathrm{mg} \mathrm{L}^{-1} \text {. Reduced } \\
\text { leaf dimension - Cu: } 0.5 \mathrm{mg} \mathrm{L}^{-1} \text {; } \\
\mathrm{Pb}: 50 \mathrm{mg} \mathrm{L}^{-1} \text {. Increased leaf } \\
\text { asymmetry - Cu: } 2 \mathrm{mg} \mathrm{L}^{-1} \text {. }\end{array}$ & $\begin{array}{l}\text { Reduced growth rate of the } \\
\text { seagrass observed both in } \mathrm{Pb} \text { and } \\
\text { Cu treatments; leaf size of the plant } \\
\text { reduces as the metal concentrations } \\
\text { increase and when the plants are } \\
\text { exposed to the metals for longer } \\
\text { duration; increased leaf asymmetry } \\
\text { more apparent at the } 2 \text { ppm Cu } \\
\text { treatment; no increase in fluctuating } \\
\text { asymmetry in Pb treatments; the } \\
\text { mortality of leaves is especially high } \\
\text { in Cu treatments. }\end{array}$ & [96] \\
\hline
\end{tabular}

Table 4: Biological responses in seagrasses exposed to dissolved trace elements under laboratory or field conditions. EDTA: ethylenediaminetetraacetic acid; PSII: photosystem II; PoMT2k: Posidonia oceanica Metallothionein (MT) 2k, an important metal tolerance gene; PoCMT1: one member of the Posidonia oceanica chromomethylase (CMT) family, a DNA methyltransferase. Fv: variable fluorescence; Fm: maximum fluorescence; $\Delta \mathrm{F}$ : fluorescence yield; Fm': light-adapted maximal fluorescence.

and through the formation of "banquettes" (wedge-shaped deposits of P. oceanica leaf litter). P. oceanica shoots build up structurally complex ecosystems, providing adequate life conditions and ecological niches for an important number of organisms. P. oceanica plays a crucial role in the coastal biogeochemical cycles: it modifies chemical properties (nutrient, oxygen, organic matter and dissolved inorganic carbon concentrations) of both water column and sediments; the high diurnal rates of oxygen production support respiration of a significant amount of heterotroph organisms; its presence enhances the nutrient recycling by the heterotroph bacteria; the important formation of matte, and associated long-term burial of organic matter, is a significant carbon sink. P. oceanica is also an important food supplier: direct herbivory, generally regarded as limited (only $10 \%$ - up to $70 \%$ locally - of living $P$. oceanica organic matter would enter the food webs); detritivory (detritivores feeding on litter rely on micro-organisms colonizing detritus to achieve nutritional balance); epiphyte consumers (epiphyte can represent more than $40 \%$ of the total foliar biomass of $P$. oceanica).

\section{Seagrasses as bioindicator species}

Posidonia oceanica descriptors: $P$. oceanica is used since decades as a powerful integrator of the overall quality of Mediterranean marine coastal waters (e.g., Ref. [117-120]). This large-size long-living species, sedentary and abundant, colonizes the major part of the Mediterranean coasts where it can be easily collected. It is sensitive to chemical pollution and mechanical disturbances $[12,117,121]$ and makes account, by its presence and its vitality (or its regression materialized by dead matte), of the quality of the Mediterranean coastal waters [12]. The footprint of the quality of waters on $P$. oceanica is permanent. Consequently, many environmental parameters may be recorded by $P$. oceanica meadows [12]. In 2005, 39 scientists from as many as 23 Research Centres synthetized in a common publication the descriptors of $P$. oceanica in order to better define the respective advantages of each one to assess the good ecological status of coastal zones [121]. Descriptors covered all the levels of organization of $P$. oceanica meadows, from the biochemical composition of the seagrass to the structure of the entire ecosystem.

In summary: chemical and biochemical composition of $P$. oceanica can provide information about the level of plant stress, and seems in adequacy with the level and impact of human activities; levels of contaminants provide information about the overall pollution of the meadow; leaf biometry is indicative of the environmental conditions (anthropisation, water motion, action of grazers etc.) and the dynamics and vegetative growth of the meadow; lepidochronology (cyclic changes along rhizomes) $[122,123]$ and plastochrone interval index (an interpolation method used to estimate leaf age) [124] provide information about the temporal evolution of primary production, sedimentation rates, sexual reproduction and dynamics of the meadow; structural characteristics of the meadow (shoot density, bottom cover, speed of growth of rhizomes and matte structure) provide information on the vitality, the macrostructure and dynamics of the meadow, as well as information on sedimentation, hydrodynamism, currents or human impacts; lower and upper limits provide pertinent information about the quality of the meadow and environmental changes, both natural and human-induced (e.g., water transparency, hydrodynamics, sedimentary balance, coastal developments, anchorage etc.); disappearance of the seagrass bed is indicative of the freshening at the outlets of coastal rivers or groundwater; associated species (fauna and flora) supply relevant information concerning the biodiversity of the meadow and the interactions meadow-species; epiphytes also provide information on water quality, especially data on nutrients inputs $[12,121]$.

Natural and human-induced disturbances experimented by $P$. oceanica meadows (e.g., eutrophication, decrease of water transparency, 
water motion) and the time of answer of their various related descriptors (hours to decades) vary greatly. A better understanding of the complexity and interactions of these disturbances thus requires a global approach combining different descriptors [121].

The choice of proper descriptors: Martínez-Crego et al. [125] identified from the literature 59 seagrass descriptors sensitive to environmental changes at different levels of biological organisation, for the most identical to the ones summarized in Pergent-Martini et al. [121]. Authors validated these descriptors on deep $(15 \mathrm{~m})$ and shallow (5 m) P. oceanica meadows from the Catalan coast (Spain) covering a wide anthropogenic gradient ranging from undisturbed to severely disturbed sites. Numerous descriptors were discarded: either because they failed to detect large scale (i.e., between-site) variability due to the masking effect of high spatial heterogeneity at smaller scales (i.e., variability between zones; e.g., number of leaves, amino acid contents in rhizomes etc.); either because they were influenced by natural sources of variability such as herbivory or physical settings and showed a low efficiency in ordering deep meadows (e.g., herbivore bite marks, leaf length and width etc.); or because, although they seemed to be linked to environmental status or to specific pollutants, responses of these indicators appeared to be influenced by interactions between different sources of pollution (e.g., interactions between metals and nutrients, interactions between different sources of anthropogenic nitrogen etc.). Among the 59 seagrass descriptors assessed, only 16 were finally unequivocally related to the environmental status gradient under study (among them, 7 concerned TEs); they were representative of physiological (e.g., carbohydrates), biochemical (e.g., TEs), individual (e.g., shoot necrosis), and population (e.g., meadow cover) levels of biotic organisation. Their combination was necessary to cover the entire environmental gradient and to reflect the multiple anthropogenic disturbances causing the gradient [125].

The choice of an adequate suite of indicators appears thenceforth decisive to ensure the consistency of multimetric indices and to provide an ecologically relevant interpretation of the response of biota to multiple stressors [125]. Such multimetric indices, however simplified (i.e., less descriptors) for convenience of application, have been experimented to assess the ecological status of $P$. oceanica meadows, as for example: the POMI index (Posidonia oceanica multivariate index) [126,127], the BiPo index (Biotic index using Posidonia oceanica) [128], or the PREI index (Posidonia oceanica Rapid Easy Index) [129]. These indices need the destructive sampling of shoots from the meadow in order to measure some of the indicators required for their calculation. However, $P$. oceanica being a protected species, the monitoring of the state of conservation of the Mediterranean coastline using $P$. oceanica must therefore evolve toward the implementation of less invasive methods [130] and toward the development of non-destructive index, as proposed by Gobert et al. [131].

\section{TE bioaccumulation in seagrasses}

Posidonia oceanica as model: In the Mediterranean, $P$. oceanica is regarded as a powerful indicator of bioavailable TEs since it highly bioconcentrates these chemicals. Thus, biconcentration factors from filtered seawater to $P$. oceanica leaves ranged between 2,000 and 36,000 for $\mathrm{Cd}, \mathrm{Cr}, \mathrm{Cu}, \mathrm{Pb}$ and $\mathrm{Zn}$ in two uncontaminated Italian areas $[132,133]$. P. oceanica further accumulates TEs at levels reflecting the contaminantion status of its environment (water and sediments) as shown from experiments and field studies (e.g., Ref. [134-139]). In addition, $P$. oceanica ability to record the past levels of contaminants coupled to the dating possibilities offered by the lepidochronology provide relevant biological archives about the temporal evolution of the coastal contamination in the Mediterranean (e.g., Ref. [140-143]).

Seagrass meadows can be conceptualized as the juxtaposition of 5 separate components, i.e., seagrass shoots, epiphytes, associated algae and animals a ", »:, and detritus, exchanging flows of TEs between themselves and with their environment, i.e., water and sediments. This conceptualization can be drawn in energy circuit language (Figure 3). Each symbol (production, consumption, storage and flow) of the energy circuit language is rigorously and mathematically defined. By writing such a diagram, one, in essence, is writing equations describing a system. Varying the size of symbols further indicates their physical size and their importance $[144,145]$. No detailed study has so far modelled the cycling of TEs within P. oceanica meadows. Given that the exact quantification of flows and distribution of TEs between $P$. oceanica bed components remains partly poorly known, a similar size was given to symbols modelling their cycling (Figure 3) [146]. An ecological relevant size of the symbols could be gained by combining elemental analysis [147,148], TE uptake experiments [148] and mass balance analysis [147]. The model given here for $P$. oceanica community is derived from Schroeder and Thorhaug [148] work, the only detailed study to our knowledge of the global cycling of TEs within a seagrass (Thalassia testudinum) ecosystem. Since providing details on all the components of a P. oceanica meadow and their interconnecting flows would exceed the frame of this paper, particular attention will therefore be delivered to the processes directly related to the sole seagrass and its associated epiphytes. TE flows discussed in the next section will be referred to their corresponding lettered-numbered label given in Figure 3 model for clarity purpose.

TE balance within Posidonia oceanica: Sanz-Lázaro et al [147] recently demonstrated the key role played by P. oceanica (as a species, not as an ecosystem) in the cycling of TEs in Mediterranean coastal waters. These authors calculated the TE incorporation rates in $P$. oceanica rhizomes, roots and new leaves from mean tissue concentrations and tissue production rates, subtracted TE loss rates through leaf shedding, mechanical breakage (CF1) and grazing (FF1), and extrapolated the balances obtained for their reference meadow to the whole Mediterranean (Table 5, according to the estimates of the total cover of $50,000 \mathrm{~km}^{2}$ of $P$. oceanica meadows) [112]. Depending on the plant compartment where TEs were mainly accumulated and on their incorporation and loss dynamics, Sanz-Lázaro et al. [147] calculated that $P$. oceanica could act either as a sink (positive balance) or as a source (negative balance; TEs given back accessible to others components of the system or exported) for these chemicals.

Seagrass leaves provide an expanded area to sorb and sequester chemicals (UF1, UF2), and their root-rhizome system facilitates the absorption and accumulation of sediment contaminants (UF6) $[68,72]$. The extent to which these uptake processes are passive or subject to active physiological regulation will determine the final accumulation behaviour of seagrass compartments relative to the TE levels they are exposed to [149]. TEs accumulated by the leaf canopy and the rootrhizome system may afterward be translocated to below- (basipetal, TF2) or above-ground (acropetal, TF1) tissues, respectively [68,137]. TE concentrations in both above- and below-ground compartments further follow an annual cycle (e.g., Ref. $[107,136,149,150]$ ). This seasonality had been initially only attributed to variations in the plant growth dynamics that induced a dilution of the accumulated TEs [151]; but climatic patterns (seasonal rainfalls and storm frequency) leading to changes in chemical loads in the water and sediments show an equal or greater influence on this seasonality $[91,149]$. 
The only few studies that have so far monitored the levels of TEs in $P$. oceanica epiphytes reported a more important accumulation of many TEs (e.g., $\mathrm{V}, \mathrm{Cr}, \mathrm{Fe}, \mathrm{As}, \mathrm{Pb}$ etc.) in these latest compared to the other seagrass compartments $[137,147,149]$. In addition to the direct uptake of TEs from the water column (UF2), it has been suggested that their leaching from the seagrass leaves could be an important route of transfert from the plant to its epiphytes (TF4) [152]. Seagrass leaves and more certainly epiphytes (as preferential food resource for numerous grazers) [153] further represent sources of potentially toxic chemicals to the grazer community (FF1, FF2). Since epiphytes are a key component of $P$. oceanica meadows and since they are ubiquitous on the leaves of seagrass species, they should be taken more into consideration when studying TE cycling in seagrass meadows [147].

Seagrass-accumulated chemicals and those associated with the epiphytic layer can be lost to the surrounding water in a dissolved form (LF1, LF2) or be exported bound to blade fragments (CF1, CF2) at senescence [72]. Some TEs like $\mathrm{Zn}, \mathrm{Cd}, \mathrm{Sr}$ or Rb show high release rates through decomposition of $P$. oceanica detritus and are expected to be released in the meadow (LF5); a contrario, others like Cs, $\mathrm{Tl}$ or Bi show low release rates through decomposition and are more likely to be buried (MF1) or exported to adjacent ecosystems [147]. Finally, the well-developed belowground system of $P$. oceanica roots and rhizomes forming mattes can persist for thousands of years [154], thenceforth sequestrating a fraction of the accumulated and potentially toxic TEs and reducing the total amount bioavailable to other organisms $[147,155]$. Seagrasses therefore act not only as biological filters but also as storage compartments, thereby favouring the decrease of
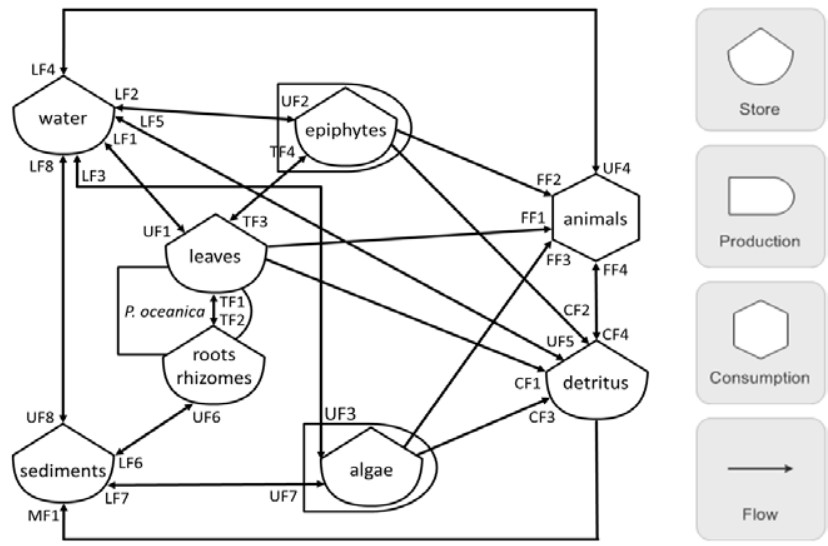

Figure 3: Trace element (TE) cycling between the different components of a $P$. oceanica meadow. Model is drawn in energy circuit language (left) and symbol meaning is given (right) [145]. In such schematic representations, varying the size of symbols indicates their physical size and their importance [144]. Given that the quantification of flows and distribution of TEs between $P$. oceanica bed components remains partly poorly known, a similar size was given to each symbol. The 29 lettered-numbered TE flows between $P$. oceanica bed components are the following: Uptake Flow (UF) leaves (UF1), epiphytes (UF2), algae (UF3) animals (UF4) and detritus (UF5) from water, roots/rhizomes (UF6) and algae (UF7) from sediments, and sediments from water (UF8); Loss Flow (LF) leaves (LF1), epiphytes (LF2), algae (LF3) animals (LF4) and detritus (LF5) to water, roots/rhizomes (LF6) and algae (LF7) to sediments, and sediments to water (LF8). Translocation Flow (TF) roots/rhizomes to leaves (TF1), leaves to roots/rhizomes (TF2), epiphytes to leaves (TF3) and leaves to epiphytes (TF4); Feeding Flow (FF) animals on leaves (FF1), epiphytes (FF2), algae (FF3) and detritus (FF4); Conversion Flow (CF) leaves (CF1), epiphytes (CF2), algae (CF3) and animals (CF4) to detritus; Mineralization Flow (MF) detritus to sediments (MF1). Flow exchanges with adjacent ecosystems are not shown (modified after Ref. [148]). environmental toxic substances [156].

\section{Mytilus spp.}

\section{Biology}

It is considered that there exist three species of mussels within the genus Mytilus - M. edulis, M. galloprovincialis and M. trossulus. M. edulis is distributed along the Atlantic coasts of Europe till high northern latitudes; $M$. galloprovincialis has a more southern repartition along the Atlantic coasts, from Britain to Morocco, and is distributed along the Mediterranean coasts. M. trossulus is distributed in the Baltic Sea [157]. In parts of Europe where species are sympatric, both hybridisation and introgression occur [157,158]. M. galloprovincialis has moreover become invasive in many parts of the world, including in Australia, Asia, California and the Puget Sound in the United States, and in South Africa [159]. Under optimal conditions, M. edulis and M. galloprovincialis attain a shell length of $100-130 \mathrm{~mm}$, whereas in marginal conditions, mussels may measure as little as $20-30 \mathrm{~mm}$. Feeding and respiration are carried out via currents of water directed across the gills. Food particles, trapped by cilia, are conveyed towards the labial palps and mouth. Mussels can also actively transport DOM across their gill membrane and utilise it as a nutritional supplement [160].

Reproduction in Mytilus spp. follows an annual seasonal cycle. Gametogenesis and energy storage occur in the mantle tissue, where a large shift in cell types (adipogranular cells and vesicular connective tissue vs. gametes) is evident throughout the annual cycle [161]. Sex of mature individuals can be told by the colour of their gonads: pink to orange for females and creamy-white to yellow for males [162]. After spawning, this sex segregation based on mantle colour is not possible anymore as mantle becomes thin and translucent [162,163]. In M. galloprovincialis collected in Galicia (Spain), spawning occurs from spring until late August or September [164]; along the French Mediterranean coasts, preponderant spawning occurs in January/ February and partial spawning is observed in April/June [165,166]. As most studies regarding the uptake and elimination kinetics of TEs implicitly assume steady-state conditions for physiological processes, i.e., without a reproductive period [167], the knowledge of mussel reproductive cycle in the area under study is a necessary prerequisite to their use as bioindicator species.

\section{Mytilus spp. as bioindicator species}

Quality indicators: It is the unique combination of biomonitoring features Mytilus spp. exhibit that make them particularly well suited as indicator species [101,168]. They have a broad geographical distribution, ranging from temperate to subarctic regions, and colonize, as euryhalin, estuarine to fully marine waters. Because they are keystone species, it is likely that a pollutant that affects a mussel population will also exhibit a negative impact for the entire ecosystem. As longliving sessile organisms they can integrate the contaminations of their environment over long time periods. Mussels are relatively large, easy to handle, and can be used under laboratory and field conditions. They accumulate chemicals both from their diet (via the gastro-intestinal tract) and from the ambient water (via the tissue membranes in contact with water), exhibit only a limited ability to eliminate pollutants and reach higher bioaccumulation factors than other systematic groupings for many toxicants. Consequently, pollutants might exhibit negative impacts on mussels at lower environmental concentrations, facilitating their use as an ecological early warning system. The histomorphology and the physiology of Mytilus spp. being well characterised, effects of 


\begin{tabular}{|c|c|c|c|c|}
\hline & Trace element & Balance & World prod. & Equivalence \\
\hline & $\mathrm{Fe}$ & 1,891 & $2,590,000$ & $0.07 \%$ \\
\hline & $\mathrm{Ni}$ & 175 & 1,590 & $11 \%$ \\
\hline & $\mathrm{Cr}$ & 30 & 7,290 & $0.41 \%$ \\
\hline & As & 4.6 & 52.8 & $8.70 \%$ \\
\hline & $\mathrm{Ag}$ & 3.6 & 23.1 & $16 \%$ \\
\hline \multirow{7}{*}{ 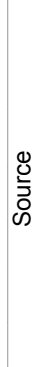 } & $\mathrm{Pb}$ & -8 & 4,140 & $0.19 \%$ \\
\hline & $\mathrm{Cd}$ & -11 & 21 & $53 \%$ \\
\hline & Co & -21 & 90 & $24 \%$ \\
\hline & V & -38 & 58 & $67 \%$ \\
\hline & $\mathrm{Cu}$ & -45 & 16,000 & $0.28 \%$ \\
\hline & $\mathrm{Mn}$ & -587 & 43 & $1375 \%$ \\
\hline & $\mathrm{Zn}$ & $-1,459$ & 12,000 & $12 \%$ \\
\hline
\end{tabular}

Table 5: Annual balances of trace element (TE) amounts in Posidonia oceanica (tons $\mathrm{y}^{-1}$ ) for the whole Mediterranean [147]. Positive or negative amounts indicate either incorporation or release by $P$. oceanica, respectively. These balances, expressed in equivalent $\%$ to the 2010 mean world production (tons $\mathrm{y}^{-1}$; see Table 1 ), reflect the quantitative importance of the role played by this species in the cycling of TEs.

environmental stresses can be measured at various levels of biological organisation (from molecules to communities). They further are non-controversial as organisms for ecotoxicological research. Finally, as shellfish products, they are a potential source of contaminant exposure for humans. For all these reasons, mussels are very widely used in programs monitoring the chemical contamination of the marine coastal environment (e.g., Ref. [169-172]). Furthermore, consensual methods developed for optimizing the use of Mytilus spp. as comparative quantitative indicators make their wide use as environmental monitoring tool strongly relevant $[101,173]$.

Pollution monitoring: The level of contaminants in the flesh of mussels reflects the level of bioavailable contaminants in the water [174]. It results from a balance between the concentration in the organism and its environment, which depends on the processes of absorption, excretion and accumulation [101]. Based on the use of these molluscs for monitoring purposes, two types of monitoring strategies have been adopted: passive or active biomonitoring. Passive biomonitoring surveys rely on the use of native populations of wild or cultivated mussels (e.g., the Mussel Watch Program in the USA, Ref. [171], the RNO program in France, Ref. [175]); active biomonitoring surveys resort to transplants of individuals (e.g., RINBIO and MYTILOS programs in the Mediterranean, Ref. [176,177]). In the latter case, caged mussels are immerged on-site during their sexual dormancy for several months so they can accumulate contaminants to balance with their transplantation environment.

The biomonitoring of contaminants in coastal waters is mostly carried out by direct quantification of the accumulated pollutants within individuals (e.g., Ref. [176,178-182]). However, the monitoring of biological responses to pollutants (or biomarkers) at the molecular and cellular level has been showed to be a useful complementary tool in environmental quality evaluation and risk assessment $[183,184]$. Alteration in specific biomarkers reflect the type of pollution organisms are facing. For example, metallothioneins and the enzyme d-aminolevulinic acid dehydratase are indicative of metal contamination, the mixed function oxidase system, glutathione
S-transferase and acetylcholinesterase are indicative of organic contamination and superoxide dismutase, catalase, glutathione peroxidase and lipid peroxidation are biomarkers of oxidative stress. A multibiomarker approach therefore turns out to be a useful approach as complex mixtures of contaminants usually occur in the environment [183]. But the use of mussels as bioindicator species is not limited to the chemical contaminants. Thus, Kaçar et al. [185] showed that $M$. galloprovincialis bioconcentated microbial pollution indicators (heterotrophic bacteria and faecal coliforms) and pathogens (Salmonella spp.) and could therefore be used to prevent potentially harmful adverse effects of microorganisms from polluted waters and shellfish. Browne et al. [186] experimentally demonstrated that $M$. edulis bioaccumulated microplastic in its flesh. And Lassauque et al. [187] successfully traced sewage and natural freshwater inputs in a Northwest Mediterranean bay from carbon and nitrogen isotopic ratio measurements in M. galloprovincialis.

Seafood and human health: Mussels are commercially important seafood species. The determination of accumulated concentrations of contaminants in their flesh is essential because of the potential adverse effects of their consumption on human health $[188,189]$. In the particular case of metals, the maximum permissible limits fixed by the European Commission [190] in edible tissues of mussels are 0.5 $\mathrm{mg} \mathrm{kg}^{-1}$ for $\mathrm{Hg}$ and $1 \mathrm{mg} \mathrm{kg}^{-1}$ for $\mathrm{Cd}$ and $\mathrm{Pb}$ (related to fresh weight). Comparison of the concentrations determined in the soft tissues of M. galloprovincialis sampled worldwide with the European legislation showed that the levels of these metals generally did not exceed the existing limits (detailed dataset in Ref. [159]). Nevertheless, these toxic elements might also pose some sanitary risks to consumers of shellfish purchased from contaminated hot spots that were identified in all the investigated seas $[159,189]$.

\section{Trace element bioaccumulation in Mytilus spp.}

Driving factors: Since the mid-70s, Mytilus spp. have been widely used to monitor the chemical contamination of coastal and estuarine ecosystems (e.g., Ref. $[101,171,176,177,191,192])$. It is well known that TE levels in aquatic organisms represent a time-integrated response to bioavailable pollutants in food and water $[193,194]$. But these levels do not depend solely on their bioavailability in the environment, since biotic and abiotic factors are further acting [101]. In Mytilus spp., biotic factors involved in determining the levels of accumulated TEs are related to the organism growth (age, size, soft tissue weight) and reproduction (sex and gametogenesis). Environmental factors essentially revolve around seasonal cycles (temperature, primary production, salinity etc.), although other parameters may also be involved (e.g., properties of TEs and their interactions, the position of mussels in the intertidal etc.). The influence of these factors must be identified and quantified so that they may be taken into account during sampling, validation of results and monitoring data interpretation (Figure 4) [101]. The environmental biomonitoring is thenceforth made complex due to the diversity of contaminant characteristics (nature, speciation, concentrations and interactions), the diversity of ecological factors (abiotic and biotic) and their variations and interactions in space and time [195].

Physiological correction: According to Amiard et al. [169], the seasonal variability of body TE concentrations can be explained primarily by the fluctuations of the mussel body mass. Variations of the mussel flesh weight are related to the availability of food in the environment but also to their ecophysiological cycle including gametogenesis and constitution of reserve substances. The gonad development leads to an increase in the body mass and, during this period, TEs present in their flesh are in some way "diluted", while 
they are "concentrated" when their body mass decreases at the release of the breeding material. The same goes for an increase/decrease in body mass linked to a high/low availability of food (e.g., Ref. [99,196198]). A comparison of the raw concentrations between mussels from sites with different trophic and physicochemical characteristics is thenceforth not possible and an adjustment of the data is requested [176]. For this reason, the French Research Institute for Exploitation of the Sea (the IFREMER, that monitors the coastal contamination of France, its overseas departments and territories and the whole Mediterranean littoral) adjusts the concentrations of pollutants measured in caged mussels in the frame of their Mussel Watch Programs with a condition index corresponding to the ratio of the flesh dry weight on the shell dry weight. This condition index has the advantage of being easy to measure, of being a global index comprising several physiological factors (nutrition, reproduction, etc.) [199], and seems to be the biometric variable which is the more closely related to tissue concentrations for a large panel of contaminants [176]. Thus, for TEs, the tissue concentration is inversely proportional to the condition index. Once "adjusted", monitored concentrations can be accurately intercompared between sites and studies [176]

\section{Conclusion}

Unlike organic pollutants that can be degraded to less harmful components by biological or chemical processes, TEs are considered as non-degradable pollutants that will accumulate in coastal environnements (mainly in sediments) to levels that might be toxic to the biota. Their toxic properties result from complex interactions between numerous biotic and abiotic factors; the understanding of this complex mechanistic therefore requires both laboratory and field toxicological studies with adequate model organisms. In addition, because of the remobilization processes of chemicals between environmental compartments (e.g., from sediments to the water column), the adverse effects of TE pollution in contaminated environments can remain substantial and long lasting in spite of years of restoration efforts. For these reasons, the monitoring of the contamination by TEs still remain an environmental issue of great concern for the biota, but also for human beings. When compared with the conventional chemical analysis of physical environments (i.e., air, water, soils and sediments), the monitoring relying upon the biota exhibits obvious predominance, mainly because it provides an assessment of the portions of contaminants that are available for uptake and accumulation by aquatic organisms. The election of an appropriate bioindicator organism must meet a set of objective criteria, the first being to accumulate chemicals to levels representative of the contamination status of its environnement. For the coastal Mediterranean, we confirm that the two main bioindicator species, i.e., the seagrass Posidonia oceanica and the mussel Mytilus galloprovincialis, are indeed appropriate indicators species for TE contamination monitoring [107,137-139,198,200]; and globally, we consider that seagrasses and bivalve mollusks have to be considered among the most suitable environmental indicator organisms because of their large geographical distribution, but also because of their complementarity (according to their lifestyle) as bioindicator species of chemical contamination. In addition, seagrasses form productive and biologically complex coastal ecosystems; the study of specific seagrass descriptors from the molecular to the ecosystem level thus allow to monitor the impact of anthropogenic activities at all levels of biological organization. Finally, bivalve molluscs are commercially important seafood products. Their use as biondicator firstly provides relevant information on the quality of water bodies where fish and shelfish products are grown, but also provides important phytosanitary data

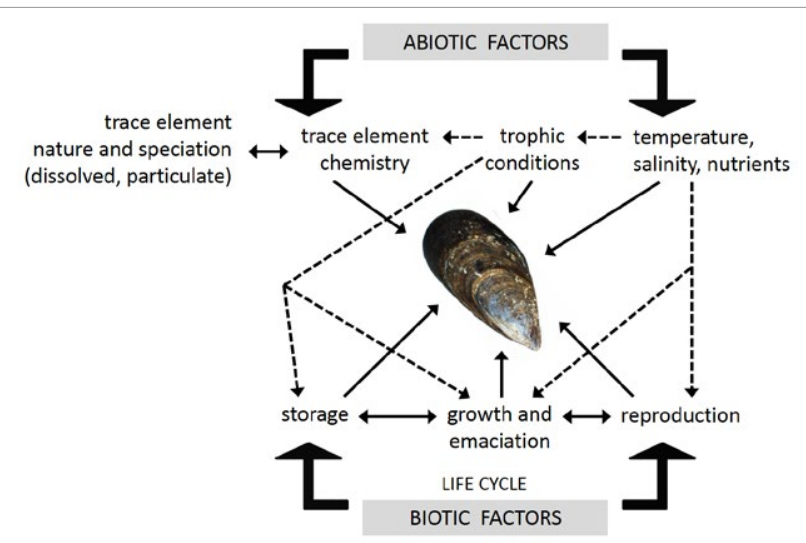

Figure 4: Schematic representation of major biotic and abiotic factors governing trace element concentration levels in mussels (modified after Ref. [101]).

on the safety of seafood consumption and potential threats to human health.

\section{Acknowledgements}

Funding was provided by the University of Liège (TRANSPOLMED, Fonds spéciaux), by the FRS-FNRS (FRFC 2.4.502.08) and by the French Community of Belgium (ARC Race 05/10-333). This study is part of the STARECAPMED (STAtion of Reference and rEsearch on Change of local and global Anthropogenic Pressures on Mediterranean Ecosystems Drifts) project funded by the Territoria Collectivity of Corsica and by The French Water Agency (PACA-Corsica). Authors are grateful to three anonymous Reviewers for constructive comments on previous version of the paper and to A. Nackers who improved the language of the manuscript. This publication has the MARE publication number MARE319.

\section{References}

1. Salomidi M, Katsanevakis S, Borja A, Braeckman U, Damalas D, et al. (2012) Assessment of goods and services, vulnerability, and conservation status of European seabed biotopes: A stepping stone towards ecosystem-based marine spatial management. Mediterranean Marine Science 13: 49-88.

2. Halpern BS, Selkoe KA, Micheli F, Kappel CV (2007) Evaluating and ranking the vulnerability of global marine ecosystems to anthropogenic threats. Conserv Biol 21: 1301-1315.

3. Halpern BS, Walbridge S, Selkoe KA, Kappel CV, Micheli F, et al. (2008) A global map of human impact on marine ecosystems. Science 319: 948-952.

4. Costanza R, D'Arge R, De Groot R, Farber S, Grasso M, et al. (1997) The value of the world's ecosystem services and natural capital. Nature 387: 253-260.

5. Hughes TP, Baird AH, Bellwood DR, Card M, Connolly SR, et al. (2003) Climate change, human impacts, and the resilience of coral reefs. Science 301 : 929-933.

6. Worm B, Barbier EB, Beaumont N, Duffy JE, Folke C, et al. (2006) Impacts of biodiversity loss on ocean ecosystem services. Science 314: 787-790.

7. Bianchi CN, Morri C (2000) Marine biodiversity of the Mediterranean Sea Situation, problems and prospects for future research. Marine Pollution Bulletin 40: 367-376.

8. Boudouresque CF (2004) Marine biodiversity in the Mediterranean: status of species, populations and communities. Scientific Report of Port-Cros National Park 20: 97-146.

9. Levin LA, Boesch DF, Covich A, Dahm C, Erseus C, et al. (2001) The function of marine critical transition zones and the importance of sediment biodiversity. Ecosystems 4: 430-451.

10. Occhipinti-Ambrogi A, Savini D (2003) Biological invasions as a component of global change in stressed marine ecosystems. Mar Pollut Bull 46: 542-551.

11. Ardizzone G, Belluscio A, Maiorano (2006) Long-term change in the structure of a Posidonia oceanica landscape and its reference for a monitoring plan. Marine Ecology - An Evolutionary Perspective 27: 299-309.

12. Boudouresque CF, Bernard G, Bonhomme P, Charbonnel E, Diviacco G, et al. (2006) Préservation et conservation des herbiers à Posidonia oceanica. 
Citation: Richir J, Gobert S (2016) Trace Elements in Marine Environments: Occurrence, Threats and Monitoring with Special Focus on the Coastal Mediterranean. J Environ Anal Toxicol 6: 349. doi:10.4172/2161-0525.1000349

\section{RAMOGE pub.}

13. Turley CM (1999) The changing Mediterranean Sea: A sensitive ecosystem? Progress in Oceanography 44: 387-400.

14. Saliot A (2005) The Mediterranean Sea. The Handbook of Environmental Chemistry. Springer-Verlag, Berlin Heidelberg.

15. Benoit G, Comeau A (2005) Méditerranée, Les perspectives du Plan bleu sur l'environnement et le développememnt. de l'Aube et Plan Bleu. p: 428

16. Augier H (2010) Guide des fonds marins de Méditerranée - Ecologie, flore faune, plongée. Delachaux et Niestlé, Paris, France.

17. Bethoux JP, Gentili B, Morin P, Nicolas E, Pierre C, et al. (1999) The Mediterranean Sea: A miniature ocean for climatic and environmental studies and a key for the climatic functioning of the North Atlantic. Progress in Oceanography 44: 131-146.

18. McNaught AD, Wilkinson A (1997) Compendium of Chemical Terminology: The Gold Book. 2nd edn. Blackwell Science, London.

19. Navratil T, Minarik L (2011) Trace Elements and Contaminants. In: Cilek V, Smith RH (Eds.), Earth System - History and Natural Variability. Global Natural Cycles. EOLSS Publishers, Oxford. p: 30.

20. Duffus JH (2002) "Heavy metals" - A meaningless term? (IUPAC technical report). Pure and Applied Chemistry 74: 793-807.

21. Kabata-Pendias A (2011) Trace Elements in Soils and Plants. 4th edn. CRC Press. Taylor \& Francis Group, New York, USA.

22. Markert B, Friese K (2000) Trace Elements - Their Distribution and Effects in the Environment. Trace Metals in the Environment.

23. WHO (1996) Trace elements in human nutrition and health. WHO Library Cataloguing, Geneva. p: 361

24. WHO (2004) Vitamin and mineral requirements in human nutrition: sd edition WHO Library Cataloguing-in- Publication Data, Geneva.

25. Amiard JC (2011) Les risques chimiques environnementaux: méthodes d'évaluation et impacts sur les organismes. Tec \& doc- Lavoisier, Paris, France.

26. Nordberg GF, Fowler BA, Nordberg M, Friberg LT (2007) Handbook on the Toxicology of Metals. 3rd edn. Elsevier Inc.

27. Kesle SE (2007) Mineral supply and demand into the 21st century. US Geological Survey Circular. pp: 55-62.

28. Tiess G (2010) Minerals policy in Europe: Some recent developments. Resources Policy 35: 190-198.

29. Sievers H, Buchholz P, Huy D (2010) Evaluating supply risks for mineral raw materials. POLINARES working paper 27: 13.

30. Daughton CG (2004) Non-regulated water contaminants: Emerging research. Environmental Impact Assessment Review 24: 711-732.

31. Daughton CG (2005) Emerging chemicals as pollutants in the environment: A 21st century perspective. Renewable Resources Journal 23: 6-23.

32. Moskalyk RR, Alfantazi AM (2003) Processing of vanadium: A review. Minerals Engineering 16: 793-805

33. Shtangeeva I, Bali R, Harris A (2011) Bioavailability and toxicity of antimony Journal of Geochemical Exploration 110: 40-45.

34. Filella M, Belzile N, Chen YW (2002) Antimony in the environment: A review focused on natural waters - I. Occurrence. Earth-Science Reviews 57: 125-176.

35. Fowler BA, Sexton MJ (2007) Bismuth. In: Nordberg GF (Ed), Handbook on the Toxicology of Metals. Elsevier Inc. pp: 433-443.

36. Beckett WS, Nordberg GF, Thomas WC (2007) Routes of exposure, dose, and metabolism of metals. In: Nordberg GF (Eds), Handbook on the Toxicology of Metals. Elsevier Inc. pp: 39-64.

37. WHO (2011) Guidelines for drinking-water quality: fourth edition. WHO Library Cataloguing-in-Publication Data, Geneva. p: 564

38. van Leeuwen FX (2000) Safe drinking water: the toxicologist's approach. Food Chem Toxicol 38: S51-58.

39. EPA (2009) List of contaminants and their maximum contaminant level (EPA 816-F-09-0004). United States Environmental Protection Agency.
40. HC (2014) Guidelines for Canadian Drinking Water Quality - Summary Table. Water, Air and Climate Change Bureau, Healthy Environments and Consumer Safety Branch, Health Canada, Ottawa, Ontario, Canada.

41. COT (2008) COT Statement on the 2006 UK Total Diet Study of Metals and other Elements. The Committee on Toxicity of Chemicals in Food, Consumer Products and the Environment, London.

42. Schwarzenbach RP, Egli T, Hofstetter TB, Von Gunten U, Wehrli B (2010) Global water pollution and human health. Annual Review of Environment and Resources 35: 109-136.

43. Järup L (2003) Hazards of heavy metal contamination. Br Med Bull 68: 167182.

44. Pan J, Plant JA, Voulvoulis N, Oates CJ, Ihlenfeld C (2010) Cadmium levels in Europe: implications for human health. Environ Geochem Health 32: 1-12.

45. Salem HM, Eweida EA, Farag A (2000) Heavy metals in drinking water and their environmental impact on human health. Proceedings of the International Conference for Environmental Hazard, Cairo, Egypt. pp: 542- 556.

46. Goldhaber SB (2003) Trace element risk assessment: essentiality vs. toxicity. Regul Toxicol Pharmacol 38: 232-242.

47. Callender E (2003) Heavy metals in the environment - Historical trends. In Holland HD, Turekian KK (Eds), Treatise on Geochemistry 99: 67-105.

48. Nriagu JO (1990) Global metal pollution. Environment Science and Policy for Sustainable Development 32: 7-33.

49. Nriagu JO (1989) A global assessment of natural sources of atmospheric trace metals. Nature 338: 47-49.

50. Bethoux JP, Courau P, Nicolas E, Ruizpino D (1990) Trace metal pollution in the Mediterranean Sea. Oceanologica Acta 13: 481-488.

51. PNUE/PAM (2009) Etat de l'environnement et du développement en Méditerranée. PNUE/PAM-Plan Bleu, Athènes.

52. Tanaka $Y$ (2006) Regulation of land-based marine pollution in international law: A comparative analysis between global and regional legal frameworks. Zeitschrift für ausländisches öffentliches Recht und Völkerrecht 66: 535-574.

53. UN (2004) Oceans and the law of the sea. United Nations general assembly, report of the Secretary-General, A/59/62/Add.1.

54. Pan K, Wang WX (2012) Trace metal contamination in estuarine and coastal environments in China. Sci Total Environ 421-422: 3-16.

55. Doney SC (2010) The growing human footprint on coastal and open-ocean biogeochemistry. Science 328: 1512-1516.

56. Bruland KW, Lohan MC (2003) Controls of Trace Metals in Seawater. In Holland HD, Turekian KK (Eds) The Oceans and Marine Geochemistry 6: 23-47.

57. Ahlf W, Drost W, Heise S (2009) Incorporation of metal bioavailability into regulatory frameworks-metal exposure in water and sediment. Journal of Soils and Sediments 9: 411-419.

58. McGeer J, Henningsen G, Lanno R, Fisher N, Sappington K, et al. (2004) Issue paper on the bioavailability and bioaccumulation of metals. US Environmental Protection Agency, Lexington, MA.

59. Goldberg ED (1954) Marine Geochemistry 1. Chemical Scavengers of the Sea The Journal of Geology 62: 249-265.

60. Turekian KK (1977) The fate of metals in the oceans. Geochimica et Cosmochimica Acta 41: 1139-1144.

61. Burton Jr GA (2010) Metal bioavailability and toxicity in sediments. Critica Reviews in Environmental Science and Technology 40: 852-907.

62. Batley GE, Apte SC, Stauber JL (2004) Speciation and bioavailability of trace metals in water: Progress since 1982. Australian Journal of Chemistry 57: 903919

63. Rainbow PS (2002) Kenneth Mellanby Review Award. Trace meta concentrations in aquatic invertebrates: why and so what? Environ Pollut 120 497-507.

64. Chapman PM (2008) Environmental risks of inorganic metals and metalloids A continuing, evolving scientific odyssey. Human and Ecological Risk Assessment 14: 5-40.

65. Wallace WG, Lee BG, Luoma SN (2003) Subcellular compartmentalization of 
Citation: Richir J, Gobert S (2016) Trace Elements in Marine Environments: Occurrence, Threats and Monitoring with Special Focus on the Coastal Mediterranean. J Environ Anal Toxicol 6: 349. doi:10.4172/2161-0525.1000349

$\mathrm{Cd}$ and $\mathrm{Zn}$ in two bivalves. I. Significance of metal-sensitive fractions (MSF) and biologically detoxified metal (BDM). Marine Ecology Progress Series 249 183-197.

66. Wallace WG, Luoma SN (2003) Subcellular compartmentalization of Cd and $\mathrm{Zn}$ in two bivalves. II. Significance of trophically available metal (TAM). Marine Ecology Progress Series 257: 125-137.

67. Mayer-Pinto M, Underwood AJ, Tolhurst T, Coleman RA (2010) Effects of metals on aquatic assemblages: What do we really know? Journal of Experimental Marine Biology and Ecology 391: 1-9.

68. Ralph PJ, David T, Kenneth M, Stephanie S, Macinnis-Ng CMO (2006) Human impacts on seagrasses: Eutrophication, sedimentation, and contamination. In Larkum AWD, Orth RJ, Duarte CM (Eds), Seagrasses: Biology, Ecology and Conservation. Springer, Dordrecht, The Netherlands. pp: 567-593.

69. Chappie DJ, Burton GAJ (2000) Applications of aquatic and sediment toxicity testing in situ. Soil and Sediment Contamination 9: 219-245

70. Liber K, Goodfellow W, den Besten P, Clements W, Galloway T, et al. (2007) In situ-based effects measures: Considerations for Improving methods and approaches. Integrated Environmental Assessment and Management 3: 246 258.

71. Clements WH, Hickey CW, Kidd KA (2012) How do aquatic communities respond to contaminants? It depends on the ecological context. Environ Toxicol Chem 31: 1932-1940.

72. Lewis MA, Devereux R (2009) Nonnutrient anthropogenic chemicals in seagrass ecosystems: fate and effects. Environ Toxicol Chem 28: 644-661.

73. Fairbrother A, Wenstel R, Sappington K, Wood W (2007) Framework for metals risk assessment. Ecotoxicol Environ Saf 68: 145-227.

74. van Dam RA, Harford AJ, Houston MA, Hogan AC, Negri AP (2008) Tropical marine toxicity testing in Australia: a review and recommandations. Australasian Journal of Ecotoxicology 14: 55-88.

75. Adams MS, Stauber JL (2008) Marine whole sediment toxicity tests for use in temperate and tropical Australian environments: current status. Australasian Journal of Ecotoxicology 14: 155-167.

76. Depledge MH, Hopkin SP (1995) Methods to assess effects on brackish estuarine, and near-coastal water organisms. In: Lindhurst RA, Bourdeau P, Tardiff RG (Eds.). Methods to Assess the Effects of Chemicals on Ecosystems. pp: $125-149$

77. Bryan GW, Langston WJ, Hummerstone LG, Burt GR (1985) A guide to the assessment of heavy-metal contamination in estuaries using biological indicators. Marine Biological Association of the United Kingdom. Occasional Publication 4: 92

78. USEPA (2004) Overview of freshwater and marine toxicity tests: A technical tool for ecological risk assessment. United States Environmental Protection Agency, Davis.

79. Rosen G, Rivera-Duarte I, Kear-Padilla L, Chadwick DB (2005) Use of laboratory toxicity tests with bivalve and echinoderm embryos to evaluate the bioavailability of copper in San Diego Bay, California, USA. Environ Toxico Chem 24: 415-422.

80. Nadella SR, Fitzpatrick JL, Franklin N, Bucking C, Smith S, et al. (2009) Toxicity of dissolved $\mathrm{Cu}, \mathrm{Zn}, \mathrm{Ni}$ and $\mathrm{Cd}$ to developing embryos of the blue mussel (Mytilus trossolus) and the protective effect of dissolved organic carbon. Comp Biochem Physiol C Toxicol Pharmacol 149: 340-348.

81. Ciacci C, Barmo C, Gallo G, Maisano M, Cappello T, et al. (2012) Effects of sublethal, environmentally relevant concentrations of hexavalent chromium in the gills of Mytilus galloprovincialis. Aquat Toxicol 120-121: 109-118.

82. Millward GE, Kadam S, Jha AN (2012) Tissue-specific assimilation, depuration and toxicity of nickel in Mytilus edulis. Environ Pollut 162: 406-412.

83. Wang Q, Liu B, Yang H, Wang X, Lin Z (2009) Toxicity of lead, cadmium and mercury on embryogenesis, survival, growth and metamorphosis of Meretrix meretrix larvae. Ecotoxicology 18: 829-837.

84. King CK, Dowse MC, Simpson SL (2010) Toxicity of metals to the bivalve tellina deltoidalis and relationships between metal bioaccumulation and metal partitioning between seawater and marine sediments. Arch Environ Contam Toxicol 58: 657-665.

85. Klobucar GI, Stambuk A, Hylland K, Pavlica M (2008) Detection of DNA damage in haemocytes of Mytilus galloprovincialis in the coastal ecosystems of
Kastela and Trogir bays, Croatia. Sci Total Environ 405: 330-337.

86. Thompson B, Anderson B, Hunt J, Taberski K, Phillips B (1999) Relationships between sediment contamination and toxicity in San Francisco Bay. Marine Environmental Research 48: 285-309.

87. Long ER, Macdonald DD, Smith SL, Calder FD (1995) Incidence of adverse biological effects within ranges of chemical concentrations in marine and estuarine sediments. Environmental Management 19: 81-97.

88. Salazar MH, Duncan PB, Salazar SM, Rose KA (1995) In situ bioassays using transplanted mussels: II. Assessing contaminated sediment at a superfund site in Puget Sound. Environmental Toxicology and Risk Assessment Third Symposium. American Society for Testing and Materials STP 1218, Philadelphia. pp: 242-263.

89. Lyngby JE, Brix H (1984) The uptake of heavy metals in eelgrass Zostera marina and their effect on growth. Ecological Bulletin 36: 81-89.

90. Malea P, Haritonidis S (1996) Toxicity and uptake of aluminium by the seagrass Halophila stipulacea (forsk.) aschers, in response to aluminium exposure. Fresenius Environmental Bulletin 5: 345-350.

91. Prange JA, Dennison WC (2000) Physiological responses of five seagrass species to trace metals. Marine Pollution Bulletin 41: 327-336.

92. Ralph PJ, Burchett MD (1998) Photosynthetic response of Halophila ovalis to heavy metal stress. Environmental Pollution 103: 91-101.

93. Macinnis-Ng CM, Ralph PJ (2002) Towards a more ecologically relevan assessment of the impact of heavy metals on the photosynthesis of the seagrass, Zostera capricorni. Mar Pollut Bull 45: 100-106.

94. Macinnis-Ng CMO, Ralph PJ (2004) Variations in sensitivity to copper and zinc among three isolated populations of the seagrass, Zostera capricorni. Journal of Experimental Marine Biology and Ecology 302: 63-83.

95. Greco M, Chiappetta A, Bruno L, Bitonti MB (2012) In Posidonia oceanica cadmium induces changes in DNA methylation and chromatin patterning. $J$ Exp Bot 63: 695-709.

96. Ambo-Rappe R, Lajus DL, Schreider MJ (2011) Heavy metal impact on growth and leaf asymmetry of seagrass, Halophila ovalis. Journal of Environmental Chemistry and Ecotoxicology 3: 149-159.

97. Durako MJ (2012) Using PAM fluorometry for landscape-level assessmen of Thalassia testudinum: Can diurnal variation in photochemical efficiency be used as an ecoindicator of seagrass health? Ecological Indicators 18: 243-251.

98. Burger $J$ (2006) Bioindicators: A review of their use in the environmental literature 1970-2005. Environmental Bioindicators 1: 136-144.

99. Rainbow PS (1995) Biomonitoring of heavy metal availability in the marine environment. Marine Pollution Bulletin 31: 183-192.

100. Zhou Q, Zhang J, Fu J, Shi J, Jiang G (2008) Biomonitoring: an appealing tool for assessment of metal pollution in the aquatic ecosystem. Anal Chim Acta 606: 135-150.

101. Cossa D (1989) A review of the use of Mytilus spp. as quantitative indicators of cadmium and mercury contamination in coastal waters. Oceanologica Acta 12: 417-432.

102. Heink U, Kowarik I (2010) What are indicators? On the definition of indicator in ecology and environmental planning. Ecological Indicators 10: 584-593.

103. Blandin P (1986) Bioindicateurs et diagnostic des systémes écologiques Bulletin d'écologie 17: 211-307.

104. Rainbow PS, Phillips DJH (1993) Cosmopolitan biomonitors of trace metals. Marine Pollution Bulletin 26: 593-601.

105. Eisler R (2009) Compendium of Trace Metals and Marine Biota: Volume 1 Plants and Invertebrates. Elsevier, Amsterdam. p: 638

106. Eisler R (2009) Compendium of Trace Metals and Marine Biota: Volume 2 Vertebrates. Elsevier, Amsterdam. p: 522

107. Richir J, Gobert S (2014) A reassessment of the use of Posidonia oceanica and Mytilus galloprovincialis to biomonitor the coastal pollution of trace elements: New tools and tips. Mar Pollut Bull 89: 390-406.

108. den Hartog C (1970) The Sea-grasses of the World. A.N. Verhandelingen der Koninklijke Nederlandse Akademie van Wetenschappen. Tweede Reeks Deel 59, $N^{\circ} 1$. North-Holland Publishing Company, The Netherlands. 
Citation: Richir J, Gobert S (2016) Trace Elements in Marine Environments: Occurrence, Threats and Monitoring with Special Focus on the Coastal Mediterranean. J Environ Anal Toxicol 6: 349. doi:10.4172/2161-0525.1000349

109. Phillips RC, Menez EG (1988) Seagrasses. Smithsonian Contributions to the Marine Sciences. Smithsonian Institution Press, Washington DC.

110. Procaccini G, Buia MC, Gambi MC, Perez M, Pergent G, et al. (2003) The seagrasses of the western Mediterranean. In: Green EP, Short FT (Eds). World Atlas of Seagrasses. pp: 48-58.

111. Augier $H$, Robert $P$, Maffre $R$ (1980) Etude du régime thermique annuel des eaux au niveau des peuplements de Phanérogames marines de la baie de Port-Cros (îles d'Hyères, Méditerranée, France). Travaux scientifiques Parc national de Port-Cros 6: 69-131.

112. Pasqualini V, Pergent-Martini C, Clabaut P, Pergent G (1998) Mapping of Posidonia oceanica using aerial photographs and side scan sonar: Application off the Island of Corsica (France). Estuarine, Coastal and Shelf Science 47: 359-367.

113. Gobert S, Cambridge ML, Velimirov B, Pergent G, Lepoint G, et al. (2006) Biology of Posidonia. In: Larkum AWD, Orth RJ, Duarte CM (Eds.) Seagrasses: Biology, Ecology and Conservation. Springer, Dordrecht, The Netherlands. pp: 387-408.

114. Pergent G, Pergent-Martini C, Boudouresque CF (1995) Utilisation de I'herbier à Posidonia oceanica comme indicateur biologique de la qualité du milieu littoral en Méditerranée: état des connaissances. Mésogée 54: 3-27.

115. Kuo J, den Hartog C (2006) Seagrass Morphology, Anatomy, and Ultrastructure. In: Larkum AWD, Orth RJ, Duarte CM (Eds.). Seagrasses: Biology, Ecology and Conservation. Springer, Dordrecht, The Netherlands. pp: $51-87$.

116. Larkum AWD, Orth RJ, Duarte CM (2006) Seagrasses: Biology, Ecology and Conservation. Springer, Dordrecht, The Netherlands.

117. Augier H (1985) L'herbier à Posidonia oceanica, son importance pour le littoral méditerranéen, sa valeur comme indicateur biologique de l'état de santé de la mer, son utilisation dans la surveillance du milieu, les bilans écologiques et les études d'impact. Vie marine 7: 85-113.

118. Boudouresque CF, Charbonnel E, Meinesz A, Pergent G, Pergent-Martini C et al. (2000) A monitoring network based on the seagrass Posidonia oceanica in the Northwestern Mediterranean Sea. Biologie Marine Méditerranée 7 : 328-331.

119. Lopez y Royo C, Pergent G, Alcoverro T, Buia MC, Casazza G, et al. (2011) The seagrass Posidonia oceanica as indicator of coastal water quality: Experimental intercalibration of classification systems. Ecological Indicators 11: $557-563$

120. Roca G, Alcoverro $T$, de Torres M, Manzanera M, Martínez-Crego B, et al (2015) Detecting water quality improvement along the Catalan coast (Spain) using stress-specific biochemical seagrass indicators. Ecological Indicators 54: $161-170$

121. Pergent-Martini C, Leoni V, Pasqualini V, Ardizzone GD, Balestri E, et al (2005) Descriptors of Posidonia oceanica meadows: use and application. Ecological Indicators 5: 213-230.

122. Pergent G (1990) Lepidochronological analysis of the seagrass Posidonia oceanica (L) Delile - a standardized approach. Aquatic Botany 37: 39-54.

123. Pergent G, Boudouresque CF, Crouzet A, Meinesz A (1989) Cyclic changes along Posidonia oceanica rhizomes (lepidochronology) - Present state and perspectives. Marine Ecology 10: 221-230.

124. Cebrian J, Marba N, Duarte CM (1994) Estimating leaf age of the seagrass Posidonia oceanica (L.) Delile using the plastochrone interval index. Aquatic Botany 49: 59-65.

125. Martínez-Crego B, Vergés A, Alcoverro T, Romero J (2008) Selection of multiple seagrass indicators for environmental biomonitoring. Marine Ecology Progress Series 361: 93-109.

126. Romero J, Martinez-Crego B, Alcoverro T, Perez M (2007) A multivariate index based on the seagrass Posidonia oceanica (POMI) to assess ecological status of coastal waters under the water framework directive (WFD). Marine Pollution Bulletin 55: 196-204.

127. Romero J, Martinez-Crego B, Alcoverro T, Perez M (2007) Corrigendum to "A multivariate index based on the seagrass Posidonia oceanica (POMI) to assess ecological status of coastal waters under the water framework directive (WFD)". Marine Pollution Bulletin 54: 631.

128. Lopez y Royo C, Casazza G, Pergent-Martini C, Pergent G (2010) A biotic index using the seagrass Posidonia oceanica ( $\mathrm{BiPo}$ ), to evaluate ecological status of coastal waters. Ecological Indicators 10: 380-389.

129. Gobert S, Sartoretto S, Rico-Raimondino V, Andral B, Chery A, et al. (2009) Assessment of the ecological status of Mediterranean French coastal waters as required by the Water Framework Directive using the Posidonia oceanica Rapid Easy Index: PREI. Mar Pollut Bull 58: 1727-1733.

130. Montefalcone M (2009) Ecosystem health assessment using the Mediterranean seagrass Posidonia oceanica: A review. Ecological Indicators 9: 595-604.

131. Gobert S, Lejeune P, Chery A, Boissery P, Sartoretto S, et al. (2012) Assessment of the ecological status of Posidonia oceanica meadow with a "Non Destructive Shoot Method": NDSM. Proceedings of the 4th Mediterranean Seagrass Workshop, Essaouira, Morocco. p: 18.

132. Campanella L, Conti ME, Cubadda F, Sucapane C (2001) Trace metals in seagrass, algae and molluscs from an uncontaminated area in the Mediterranean. Environ Pollut 111: 117-126.

133. Conti ME, lacobucci M, Cecchetti G (2007) A biomonitoring study: trace metals in seagrass, algae and molluscs in a marine reference ecosystem (Southern Tyrrhenian Sea). International Journal of Environment and Pollution 29: 308-332.

134. Lafabrie C, Pergent G, Kantin R, Pergent-Martini C, Gonzalez JL (2007) Trace metals assessment in water, sediment, mussel and seagrass species - validation of the use of Posidonia oceanica as a metal biomonitor Chemosphere 68: 2033-2039.

135. Warnau M, Fowler SW, Teyssie JL (1996) Biokinetics of selected heavy metals and radionuclides in two marine macrophytes: The seagrass Posidonia oceanica and the alga Caulerpa taxifolia. Marine Environmental Research 41: 343-362.

136. Pergent-Martini C, Pergent G (2000) Marine phanerogams as a tool in the evaluation of marine trace-metal contamination: An example from the Mediterranean. International Journal of Environment and Pollution 13: 126-147.

137. Richir J, Luy N, Lepoint G, Rozet E, Alvera Azcarate A, et al. (2013) Experimental in situ exposure of the seagrass Posidonia oceanica (L.) Delile to 15 trace elements. Aquat Toxicol 140-141: 157-73.

138. Richir J, Salivas-Decaux M, Lafabrie C, Lopez y Royo C, Gobert S, et al. (2015) Bioassessment of trace element contamination of Mediterranean coastal waters using the seagrass Posidonia oceanica. J Environ Manage 151: 486-499.

139. Luy N, Gobert S, Sartoretto S, Biondo R, Bouquegneau JM, et al. (2012) Chemical contamination along the Mediterranean French coast using Posidonia oceanica (L.) Delile above-ground tissues: A multiple trace element study. Ecological Indicators 18: 269-277.

140. Copat C, Maggiore R, Arena G, Lanzafame S, Fallico R, et al. (2012) Evaluation of a temporal trend heavy metals contamination in Posidonia oceanica (L.) Delile, (1813) along the Western coastline of Sicily (Italy). J Environ Monit 14: 187-192.

141. Ancora S, Bianchi N, Butini A, Buia MC, Gambi MC, et al. (2004) Posidonia oceanica as a biomonitor of trace elements in the Gulf of Naples: tempora trends by lepidochronology. Environ Toxicol Chem 23: 1093-1099.

142. Pergent-Martini C, Pergent G (1994) Lepidochronological analysis in the Mediterranean seagrass Posidonia oceanica: state of the art and future developments. Oceanologica Acta 17: 673-681.

143. Gosselin M, Bouquegneau JM, Lefèbvre F, Lepoint G, Pergent G, et al. (2006) Trace metal concentrations in Posidonia oceanica of North Corsica (northwestern Mediterranean Sea): Use as a biological monitor? BMC Ecology 6: 19

144. Brown MT (2004) A picture is worth a thousand words: Energy systems language and simulation. Ecological Modelling 178: 83-100.

145. Odum HT, Odum EC (2000) Modeling for all Scales: An Introduction to System Simulation. Academic Press, San Diego, California, USA

146. Richir J, Gobert S (2014) The conceptualization of trace elements flows within Posidonia oceanica meadows: A collaborative proposal to fill knowledge gaps. 5th Mediterranean Symposium on Marine Vegetation, Portorož, Slovenia. Regional Activity Centre for Specially Protected Areas (RAC/SPA). pp: $149-154$ 
Citation: Richir J, Gobert S (2016) Trace Elements in Marine Environments: Occurrence, Threats and Monitoring with Special Focus on the Coastal Mediterranean. J Environ Anal Toxicol 6: 349. doi:10.4172/2161-0525.1000349

147. Sanz-Lázaro C, Malea P Apostolaki ET, Kalantzi I, Marín A et al. (2012) The role of the seagrass Posidonia oceanica in the cycling of trace elements. Biogeosciences 9: 2497-2507.

148. Schroeder PB, Thorhaug A (1980) Trace metal cycling in tropical-subtropica estuaries dominated by the seagrass Thalassia testudinum. American Journal of Botany 67: 1075-1088.

149. Schlacher-Hoenlinger MA, Schlacher TA (1998) Accumulation, contamination and seasonal variability of trace metals in the coastal zone - patterns in seagrass meadow from the Mediterranean. Marine Biology 131: 401-410.

150. Malea P, Haritonidis S, Kevrekidis T (1994) Seasonal and local variations of metal concentrations in the seagrass Posidonia oceanica (L.) delile in the Antikyra Gulf, Greece. Science of the Total Environment 153: 225-235.

151. Lyngby JE, Brix H (1982) Seasonal and environmental variation in cadmium copper, lead and zinc concentrations in eelgrass (Zostera marina L.) in the Limfjord, Denmark. Aquatic Botany 14: 59-74.

152. McRoy CP, Goering JJ (1974) Nutrient transfer between the seagrass Zostera marina and its epiphytes. Nature 248: 173-174.

153. Lepoint G, Nyssen F, Gobert S, Dauby P, Bouquegneau JM (2000) Relative impact of a seagrass bed and its adjacent epilithic algal community in consumer diets. Marine Biology 136: 513-518.

154. Mateo MA, Romero J, Pérez M, Littler MM, Littler DS (1997) Dynamics of millenary organic deposits resulting from the growth of the Mediterranean seagrass Posidonia oceanica. Estuarine, Coastal and Shelf Science 44: 103110.

155. Pergent G, Rico-Raimondino V, Pergent-Martini C (1997) Fate of primary production in Posidonia oceanica meadows of the Mediterranean. Aquatic Botany 59: 307-321.

156. Kaldy JE (2006) Carbon, nitrogen, phosphorus and heavy metal budgets: How large is the eelgrass (Zostera marina L.) sink in a temperate estuary? Mar Pollut Bull 52: 342-353.

157. Martinez-Lage A, Gonzalez-Tizon A, Mendez J (1995) Chromosomal markers in three species of the genus Mytilus (Mollusca: Bivalvia). Heredity 74: $369-375$

158. López JL, Marina A, Vázquez J, Alvarez G (2002) A proteomic approach to the study of the marine mussels Mytilus edulis and M. galloprovincialis. Marine Biology 141: 217-223.

159. Stankovic S, Jovic M, Stankovic AR, Katsikas L (2012) Heavy metals in seafood mussels. Risks for human health, In: Lichtfouse E, Robert D Schwarzbauer J (Eds.) Environmental chemistry for a sustainable world: Nanotechnology and Health Risk. Springer, the Netherlands 1: 62

160. Gosling E (2003) Bivalve Molluscs: Biology, Ecology and Culture. Fishing News Books, a division of Blackwell Publishing, Oxford, UK.

161. Fearman JA, Bolch CJS, Moltschaniwskyj NA (2009) Energy storage and reproduction in mussels, Mytilus galloprovincialis: The influence of diet quality. Journal of Shellfish Research 28: 305-312.

162. Mikhailov AT, Torrado M, Mendez J (1995) Sexual-differentiation of reproductive tissue in bivalve mollusks - Identification of male associated polypeptide in the mantle of Mytilus galloprovincialis Lmk. Int J Dev Biol 39 545-548.

163. Torrado M, Mikhailov AT (1998) Male-associated polypeptide (MAP) expression in different compartments of the reproductive system of the mussel Mytilus galloprovincialis: immunocytochemical and Western blot study. Cell Tissue Res 294: 537-547.

164. Mancebo MJ, Trevino M, Ferran E, Espinosa J (1992) Pattern of the mantle adenylate cyclase activity during the reproductive cycle of the female Mytilus galloprovincialis. Gen Comp Endocrinol 86: 184-188.

165. Bodin N, Burgeot T, Stanisiere JY, Bocquene G, Menard D, et al. (2004) Seasonal variations of a battery of biomarkers and physiological indices for the mussel Mytilus galloprovincialis transplanted into the northwest Mediterranean Sea. Comp Biochem Physiol C - Toxicol Pharmacol 138: 411-427.

166. Lubet $P$, Brichon $G$, Besnard JY, Zwingelstein G (1986) Sexual differences in the composition and metabolism of lipids in the mantle of the mussel Mytilus galloprovincialis LMK (Mollusca: Bivalvia). Comparative Biochemistry and Physiology Part B: Comparative Biochemistry 84: 279-285.

167. Casas S, Gonzalez JL, Andral B, Cossa D (2008) Relation between metal concentration in water and metal content of marine mussels (Mytilus galloprovincialis): Impact of physiology. Environmental Toxicology and Chemistry 27: 1543-1552.

168. Oehlmann J, Schulte-Oehlmann U (2003) Molluscs as bioindicators. In: Markert BA, Zechmeister HG (Eds), Bioindicators and biomonitors. Elsevier Science Ltd. pp: 577-635.

169. Amiard JC, Amiard-Triquet C, Berthet B, Métayer C (1986) Contribution to the ecotoxicological study of cadmium, lead, copper and zinc in the musse Mytilus edulis. Marine Biology 90: 425-431.

170. Kljakovic-Gaspic Z, Odžak N, Ujevic I, Zvonaric T, Baric A (2006) Biomonitoring of trace metals $(\mathrm{Cu}, \mathrm{Cd}, \mathrm{Cr}, \mathrm{Hg}, \mathrm{Pb}, \mathrm{Zn})$ in the eastern Adriatic using the Mediterranean blue mussel (2001-2005). Fresenius Environmental Bulletin 15: 1041-1048.

171. Goldberg ED (1986) The mussel watch concept. Environmental Monitoring and Assessment 7: 91-103.

172. Andral B, Cadiou JF, Galgani F, Tomasino C (2011) Evaluation of Chemical Contamination in the Western Mediterranean Using Mussel Transplants. In: Ceccaldi HJ (Eds), Global Change: Mankind-Marine Environment Interactions, Springer, The Netherlands, pp: 315-320.

173. Cossa D (1988) Cadmium in Mytilus spp.: Worldwide Survey and Relationship Between Seawater and Mussel Content. Marine Environmental Research 26 : 265-284.

174. Casas S, Bacher C (2006) Modelling trace metal ( $\mathrm{Hg}$ and $\mathrm{Pb}$ ) bioaccumulation in the Mediterranean mussel, Mytilus galloprovincialis, applied to environmental monitoring. Journal of Sea Research 56: 168-181.

175. Chiffoleau JF, Auger D, Roux N, Rozuel E, Santini A (2005) Distribution of silver in mussels and oysters along the French coasts: data from the national monitoring program. Mar Pollut Bull 50: 1719-1723.

176. Andral B, Stanisiere JY, Sauzade D, Damier E, Thebault H, et al. (2004) Monitoring chemical contamination levels in the Mediterranean based on the use of mussel caging. Mar Pollut Bull 49: 704-712.

177. Benedicto J, Andral B, Martínez-Gómez C, Guitart C, Deudero S, et al. (2011) A large scale survey of trace metal levels in coastal waters of the Western Mediterranean basin using caged mussels (Mytilus galloprovincialis). Journal of Environmental Monitoring 13: 1495-1505.

178. Andral B, Galgani F, Tomasino C, Bouchoucha M, Blottiere C, et al. (2011) Chemical contamination baseline in the Western basin of the Mediterranean sea based on transplanted mussels. Arch Environ Contam Toxicol 61: 261-271.

179. Galgani F, Martínez-Gómez C, Giovanardi F, Romanelli G, Caixach J, et al. (2011) Assessment of polycyclic aromatic hydrocarbon concentrations in mussels (Mytilus galloprovincialis) from the Western basin of the Mediterranean Sea. Environmental Monitoring and Assessment 172: 301-317.

180. Lobel PB, Wright DA (1983) Frequency distribution of zinc concentrations in the common mussel, Mytilus edulis (L.). Estuaries 6: 154-159.

181. Blackmore G, Wang WX (2003) Comparison of metal accumulation in mussels at different local and global scales. Environ Toxicol Chem 22: 388-395.

182. Maggi C, Ausili A, Boscolo R, Cacciatore F, Bonometto A, et al. (2012) Sediment and biota in trend monitoring of contaminants in transitional waters. TrAC Trends in Analytical Chemistry 36: 82-91.

183. Serafim A, Lopes B, Company R, Cravo A, Gomes T, et al. (2011) A multibiomarker approach in cross-transplanted mussels Mytilus galloprovincialis. Ecotoxicology 20: 1959-1974.

184. Bocchetti R, Fattorini D, Pisanelli B, Macchia S, Oliviero L, et al. (2008) Contaminant accumulation and biomarker responses in caged mussels, Mytilus galloprovincialis, to evaluate bioavailability and toxicological effects of remobilized chemicals during dredging and disposal operations in harbour areas. Aquat Toxicol 89: 257-266.

185. Kacar A (2011) Some microbial characteristics of mussels (Mytilus galloprovincialis) in coastal city area. Environ Sci Pollut Res Int 18: 1384-1389.

186. Browne MA, Dissanayake A, Galloway TS, Lowe DM, Thompson RC (2008) Ingested microscopic plastic translocates to the circulatory system of the mussel, Mytilus edulis (L.). Environmental Science and Technology 42 : 5026-5031.

187. Lassauque J, Lepoint G, Thibaut T, Francour P, Meinesz A (2010) Tracing sewage and natural freshwater input in a Northwest Mediterranean bay: 
Citation: Richir J, Gobert S (2016) Trace Elements in Marine Environments: Occurrence, Threats and Monitoring with Special Focus on the Coastal Mediterranean. J Environ Anal Toxicol 6: 349. doi:10.4172/2161-0525.1000349

Evidence obtained from isotopic ratios in marine organisms. Mar Pollut Bull 60: 843-851

188. Guéguen M, Amiard JC, Arnich N, Badot PM, Claisse D, et al. (2011) Shellfish and residual chemical contaminants: Hazards, monitoring, and health risk assessment along French coasts. Reviews of Environmental Contamination and Toxicology 213: 55-111.

189. Stankovic S, Jovic M (2012) Health risks of heavy metals in the mediterranean mussels as seafood. Environmental Chemistry Letters 10: 119-130.

190. EC (2001) Règlement (CE) N ${ }^{\circ} 466 / 2001$ de la Commission du 8 mars 2001 portant fixation des teneurs maximales pour certains contaminants dans les denrées alimentaires. Journal Officiel de L'Union européenne.

191. Cossa D, Bourget E (1980) Trace elements in Mytilus edulis L. from the estuary and gulf of St Lawrence, Canada: Lead et Cadmium concentrations. Environmental pollution 23: 1-8.

192. Odzak N, Martincic D, Zvonaric T, Branica M (1994) Bioaccumulation rate of $\mathrm{Cd}$ and $\mathrm{Pb}$ in Mytilus galloprovincialis foot and gills. Marine Chemistry 46: 119-131.

193. Wang WX, Fisher NS (1999) Delineating metal accumulation pathways for marine invertebrates. Science of the Total Environment 237-238: 459-472.

194. Croteau MN, Luoma SN (2005) Delineating copper accumulation pathways for the freshwater bivalve Corbicula using stable copper isotopes.
Environmental Toxicology and Chemistry 24: 2871-2878.

195. Casas S (2005) Modélisation de la bioaccumulation de métaux traces $(\mathrm{Hg}, \mathrm{Cd}, \mathrm{Pb}, \mathrm{Cu}$ et $\mathrm{Zn})$ chez la moule, Mytilus galloprovincialis, en milieu méditerranéen. PhD Thesis, Université du Sud, Toulon, Var, France, p: 363.

196. Cossa D, Bourget E, Pouliot D, Piuze J, Chanut JP (1980) Geographical and seasonal variations in the relationships between trace metal content and body weight in Mytilus edulis. Marine Biology 58: 7-14.

197. Cossa D, Rondeau JG (1985) Seasonal, geographical and size-induced variability in mercury content of Mytilus edulis in a estuarine environment: a re-assessment of mercury pollution level in the Estuary and Gulf of St. Lawrence. Marine Biology 88: 43-49.

198. Richir J, Gobert S (2014) The effect of size, weight, body compartment, sex and reproductive status on the bioaccumulation of 19 trace elements in ropegrown Mytilus galloprovincialis. Ecological Indicators 36: 33-47.

199. Kantin R, Pergent-Martini C (2007) Monitorage de la qualité des eaux et de l'environnement marin - Rapport final - Région Corse. Programme INTERREG IIIA Sardaigne/Corse/Toscane, MONIQUA NMCD IIIA-03/08, Convention Ifremer PAC - Equipe Ecosystèmes Littoraux \& Collectivité Territoriale de Corse MCD IIIA-03/08, Ifremer publ., La Seyne. La Seyne.

200. Richir J, Gobert S (2016) An ecophysiological discussion of trace element bioaccumulation in cultured Mytilus galloprovincialis. Belgian Journal of Zoology (In Press). 